\title{
Conservation of freshwater and euryhaline elasmobranchs: a review
}

\author{
R. Aidan Martin \\ Fish Museum, Department of Zoology, University of British Columbia, 6270 University Boulevard, Vancouver, BC V6T 1Z4, \\ Canada and ReefQuest Centre for Shark Research, PO Box 48561, 595 Burrard Street, Vancouver, BC V7X 1A3, Canada. \\ E-mail: ram@elasmo-research.org
}

Published data on the diversity, life history, ecology, and status of freshwater and euryhaline elasmobranchs was reviewed in the context of anthropogenic threats and principles of conservation biology. At least 171 species of elasmobranch, representing 68 genera and 34 families, are recorded from fresh or estuarine waters. Of these, over half are marginal in estuaries, less than one-tenth are euryhaline, and one-fifth are obligate in fresh water. Obligate freshwater elasmobranchs are dominated by myliobatoid stingrays, of which two-thirds are potamotrygonids endemic to Atlantic drainages of South America. Freshwater and euryhaline elasmobranchs adhere to strongly K-selected life histories and feed at high trophic levels, similar to those of their marine relatives. However, freshwater and euryhaline elasmobranchs are also subject to habitat constraints, notably more limited volume and physicochemical variability than the ocean, that may render them more vulnerable than marine elasmobranchs to the effects of human activities. The greatest diversity and abundance of freshwater and euryhaline elasmobranchs occur in tropical countries with enormous and rapidly increasing human populations, notably South America, West Africa, and south-east Asia. Knowledge of the biology, distribution, ecology, and status of freshwater and euryhaline elasmobranchs is frustrated by unresolved taxonomic problems, which are briefly summarized. To clarify selected issues in the conservation of freshwater and euryhaline elasmobranchs, special attention is given to sharks of the genus Glyphis, pristids, and potamotrygonids. To foster live release when possible as well as prevent discard of specimens and loss of data, an illustrated key to differentiate Carcharhinus from Glyphis sharks is provided. Obligate freshwater elasmobranchs with limited geographic ranges are deemed most vulnerable to extinction, but euryhaline elasmobranchs that require access to the sea to breed are also at significant risk. Based on the foregoing data and principles of conservation biology, suggested action plans for the conservation of freshwater and euryhaline elasmobranchs and the conservation of freshwater habitats are provided.

\section{INTRODUCTION}

Concerns over the status and conservation of elasmobranch populations around the world are being raised at an international level. Elasmobranch vulnerability to directed fishing pressure and indirect losses due to bycatch is well established (Holden, 1974; Brander, 1981; Thorson, 1982a; Compagno, 1990a; Manire \& Gruber, 1990; Bonfil, 1994; Camhi et al., 1998; Casey \& Myers, 1998; Hueter, 1998; Dulvy et al., 2000; Musick et al., 2000; Stevens et al., 2000; Fowler et al., 2002; Baum et al., 2003; Baum \& Myers, 2004). This vulnerability is regarded as a direct consequence of inherent elasmobranch life history characteristics, which feature a pattern of slow growth, late maturity, long gestation, low fecundity, and long life, resulting in a slow intrinsic rate of population increase (Hoenig \& Gruber, 1990; Pratt \& Casey, 1990; Cortés, 2000). Due to their strongly Kselected life history pattern and generally high mean trophic level (Cortés, 1999, 2000), elasmobranchs bioaccumulate heavy metals and other toxins in higher concentrations than most other groups of marine organisms (Forrester et al., 1972; Walker, 1988; Fisk et al., 2002), but the health and reproductive fitness impacts of these toxins are incompletely understood (Adamson \& Guarino, 1972; Redding, 1992; Fairey et al., 1997; Pierce \& Rand, 1997; Serrano et al., 1997; Betka \& Callard, 1999). Worldwide, many elasmobranch populations are now depleted and some are considered threatened or critically endangered (Camhi et al., 1998; Fowler et al., 2002). The long-term ecological effects of depleted elasmobranch populations are largely unknown but likely to be far-reaching (van der Elst, 1979; Cortés, 1999; Stevens et al., 2000).

Elasmobranchs are ecologically important components in virtually every marine habitat (Compagno, 1990b). All elasmobranchs are carnivorous, including euryphagous forms as well as trophic specialists such as cancritrophic, teuthotrophic, microtrophic (filter-feeding) and durophagous forms (Compagno, 1990a). Actively predaceous sharks, in particular, may play important roles in controlling population size and species diversity of their prey (Strong, 1991; Cortés, 1999). Most sharks for which adequate quantitative dietary data are available occupy relatively high trophic levels (Cortés, 1999). No comparable dietary study has been published for batoids, but most species prey upon small benthic invertebrates and teleosts (Compagno et al., 1989; Last \& Stevens, 1994; Ebert, 2003) and thus probably occupy trophic levels 
comparable to those of small- to moderate-sized benthic sharks. Thus, like marine mammals, many elasmobranchs are large and abundant 3rd or 4th order consumers and are likely to exert top-down influence in the aquatic communities of which they are part (Brooks \& Dodson, 1965; Bowen, 1997). Increasing evidence suggests that indirect effects of fishing affect the composition and diversity of elasmobranch and total fish assemblages through trophic interactions (Stevens et al., 2000). Compagno (1990b) estimated that $<5 \%$ of extant elasmobranch species occur in freshwater, but their ecological importance is poorly known.

The existence of freshwater and euryhaline elasmobranchs has been known for centuries. Perhaps the earliest reliable account of an elasmobranch in freshwater is by Zakariya al-Qazwini, who in his 1263 Arabic work, 'Wonders of Creation', recorded fierce sharks with swordlike teeth from Basrah, Iraq, some $120 \mathrm{~km}$ up the Tigris River (Zorzi, 1995). Oviedo y Valdés (1526) described sharks, sawfish, and other 'marine' fauna from the fresh waters of Lake Nicaragua. By the end of the 19th Century, sharks, sawfish, and stingrays had been reported from scattered freshwater and estuarine localities around the globe, including the Ganges-Hooghly river system of India (Hamilton-Buchanan, 1822), the Amazon River of South America (Müller \& Henle, 1838-1841) and the Fitzroy-Margaret River of north-eastern Australia (Hardman, 1884). In the Old Calabar, Ogooué, Congo, and Cross Rivers of West Africa dwells the mysterious 'ukpam', the collective term used by natives to refer to Urogymnus ukpam and other large freshwater stingrays; U. ukpam is known from fewer than a half-dozen specimens collected since its discovery in 1863-like the Yeti or Bigfoot, appearing sporadically and just often enough to keep the legend alive (Schäfer, 2001). The euryhaline shark Carcharhinus leucas has been reported as much as $4200 \mathrm{~km}$ up the Amazon (in the foothills of the Peruvian Andes), $1120 \mathrm{~km}$ up the Zambezi River, and $2800 \mathrm{~km}$ up the Mississippi River, from near Alton, Illinois (Myers, 1952; Bass et al., 1973; Thomerson et al., 1977). Wherever they occur, freshwater and euryhaline elasmobranchs have long been regarded as highly dangerous and thus to be much feared (McCormick et al., 1963; Budker, 1971).

Despite their broad (though spotty) distribution and the danger they were believed to pose, freshwater and euryhaline elasmobranchs have received little biological study. An important exception is osmoregulation, which in these hypertonic fish has long been regarded a scientific curiosity and has been studied extensively (see Evans et al., 2004 for a recent review). In contrast, the life history and ecology of freshwater and euryhaline elasmobranchs have received relatively little study. Movement of C. leucas between Lake Nicaragua and the Caribbean Sea via the rapid-laden San Juan River has been demonstrated via tagging (Thorson, 1971). Reproductive biology and feeding habits of the C. leucas (Jensen, 1976; Tuma, 1976) and reproduction and life history of Pristis perotteti in Lake Nicaragua have been studied (Thorson, 1976a, 1982b). Distribution and aspects of the biology of elasmobranchs from fresh and/or estuarine waters of the Indian River lagoon system of Florida and in North Carolina have also been studied (Snelson \& Williams, 1981; Schwartz, 1995). However, with the exception of effects of commercial fishing and dam building on neotropical populations of C. leucas and P. perotetti (Thorson, 1976b, 1982c; Montoya \& Thorson, 1982), status and conservation of freshwater and euryhaline elasmobranchs have been largely ignored until a decade ago (Compagno, 2002).

In a seminal series of papers, Compagno \& Cook (1995a,b,c) attempted to survey the diversity and distribution of all species of elasmobranch known or suspected of using freshwater or estuarine habitats, proposed a preliminary scheme for categorizing these elasmobranchs into broad habitat types, identified some of the more outstanding threats to them, and proposed a preliminary action plan for their conservation. Coasts, lakesides, riverside and streamside areas have for millennia been favoured habitats of humans, affording ready access to water, food, building materials, and transport (Renfrew \& Bahn, 1996). Humans frequently exert rapid, largescale influence on their immediate environment, including modification of water courses, pollution, hunting and fishing (Ehrlich et al., 1973). The greatest diversity and abundance of freshwater and euryhaline elasmobranchs occur in tropical countries with enormous, rapidly expanding populations (Compagno \& Cook, 1995b). Sharks and rays inhabiting estuaries and freshwater habitats are thus threatened by a collision between the effects of increasing human population and inherent biological limitations of elasmobranchs (Compagno \& Cook, 1995b).

Sharks and batoids utilizing reduced salinity habitats are subject to the same biological constraints as other elasmobranchs plus additional habitat constraints not faced by their stenohaline marine relatives. For example, freshwater systems have more limited volume and are relatively unstable physicochemically, which may exacerbate the vulnerability of freshwater and euryhaline elasmobranchs to fishing pressure and anthropogenic habitat modification (Lowe-McConnell, 1987; Moyle \& Leidy, 1992; Compagno \& Cook, 1995a). Therefore, elasmobranchs that utilize reduced salinity habitats may be more vulnerable to the effects of human activity than their marine relatives. As K-selected creatures that compete for aquatic resources against humans who widely regard them to be dangerous vermin, freshwater and euryhaline elasmobranchs present significant challenges to conservation biologists.

\section{Conservation biology: definitions and concepts}

Conservation biology adapts ecological theories and concepts to propose appropriate methodologies and implement concrete activities that facilitate nature conservation. The object of conservation biology is two-fold: (1) to ascertain the impact of human activities upon species, communities and ecosystems and (2) to make concrete proposals for averting ecosystem degradations (Lévêque \& Mounolou, 2003). Conservation biology combines science and management through three main approaches that can be encapsulated as a continuum of interacting scales: ecosystem, habitat, and species (Figure 1).

The Convention on Biological Diversity defines ecosystem as 'a dynamic complex of plant, animal, and micro-organism communities and their non-living environment interacting as a functional unit.' Ecosystem function is characterized by energy flow between organisms, 


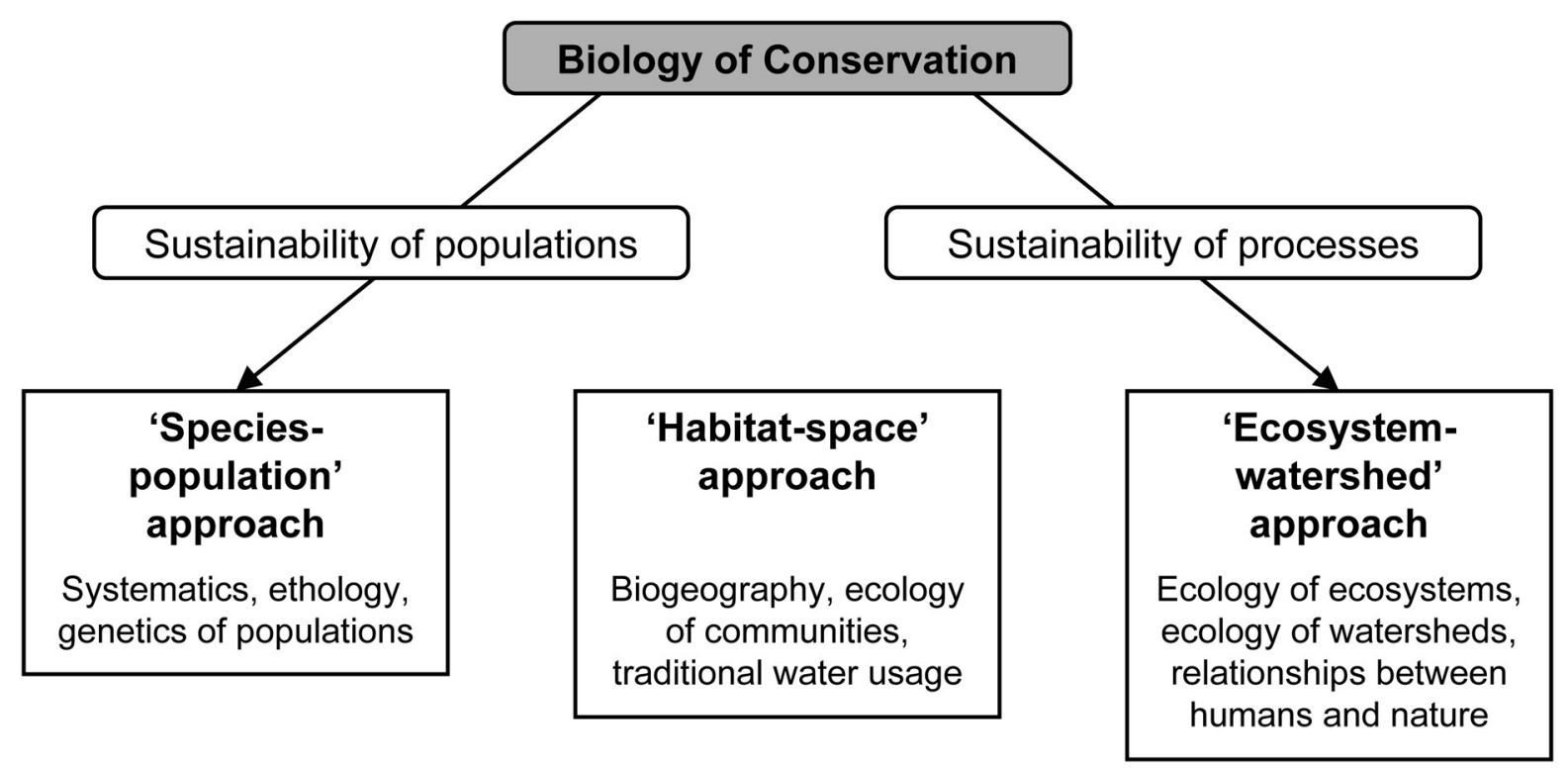

Figure 1. Three main approaches to conservation biology (modified from figure 10.1 in Lévêque \& Mounolou, 2003).

mineral and organic matter circulating via biogeochemical cycles, and food chains that impose trophic structure upon the system (Ricklefs, 1990; Krebs, 1994). As such, an ecosystem consists of two fundamentally distinct yet inseparable parts, the chemical and physical environment (biotope) and a community of living organisms (biocenosis). A core but as-yet unresolved question in ecosystem dynamics is whether a given biocenosis is a fortuitous assemblage of organisms that has succeeded in colonizing a biotope and maintaining itself or a selection of coevolved species that over time established a network of interdependencies. Many ecologists tend toward the latter theory, but substantiating these different types of interaction is proving difficult (Lévêque \& Mounolou, 2003).

The terms niche and habitat are often used interchangeably, but this is inaccurate. MacFayden (1957) defined niche as the 'set of ecological conditions under which a species can exploit a source of energy effectively enough to be able to reproduce and colonize further such sets of conditions.' Odum (1975) defined the ecological niche of a species as the role that organism plays in the ecosystem, differentiating niche from habitat as follows: 'the habitat is the address, so to speak, and the niche is the profession'. Thus, the niche of a species encompasses not only its place in the trophic network, but also its role in recycling nutrients and net effect on the biophysical environment. Presently, there is a trend to characterize ecological niches with respect to three main axes: (1) habitat axis (climatic, physical and chemical variables); (2) trophic axis (alimentary relationships); and (3) temporal axis (use of food and space resources over time). Collectively, these axes group most of the variables relevant to the physical environment (Lévêque \& Mounolou, 2003).

A population is a group of individuals of the same species occupying a clearly delimited space at the same time (Wilson, 1980). Population growth can be limited by predation, however, the dynamics of predator-prey systems are complex and depend upon local biotic and abiotic conditions (Lévêque \& Mounolou, 2003). Two polar models of population regulation that have been proposed by freshwater ecologists are termed bottom-up and top-down. The bottom-up model postulates that nutrients control community organization because nutrients control plant populations which, in turn, control herbivore numbers, and so on up the food chain. Conversely, the top-down model postulates that predation controls community organization (Krebs, 1994). Many terrestrial, marine, and freshwater ecologists have demonstrated that ecosystem functioning is highly dependent upon the predation practised by higher trophic levels on lower levels, supporting the top-down model (see Krebs, 1994, for review). By limiting the abundance of prey, predators affect the size structure, species composition, and diversity of prey populations (Paine, 1966; Estes \& Palmisano, 1974; Witte et al., 1992). The cascading trophic interaction model (Carpenter et al., 1985) predicts that removing the top carnivores from a freshwater ecosystem will increase the abundance of primary carnivores, decrease the abundance of herbivores, and increase phytoplankton abundance.

Biodiversity, in the broadest sense, is the variety of all living things, which is increasingly regarded as constituting three divisions: (1) genetic diversity; (2) species or taxonomic diversity; and (3) ecosystem diversity (Gaston, 1996). Functional biodiversity refers to the number of groups of organisms in an ecosystem that process energy and resources (nutrients, organic matter, biomass) in a similar manner (Collins \& Benning, 1996). Biodiversity erosion as a result of human activities has become a major political, economic, and ethical issue (see Lévêque \& Mounolou, 2003, for a recent review). In situ conservation of biodiversity consists of maintaining living organisms in their natural environment. Effective approaches for accomplishing this include: (1) enacting protection for endangered species; (2) improving management plans; and (3) establishing reserves to protect particular species or unique genetic resources (Lévêque \& Mounolou, 2003). In situ conservation allows plant and animal 
communities to continue to adapt and comprises a large number of species without need for preliminary inventorying. However, in situ conservation is not always possible, as many habitats are seriously disturbed and some have disappeared entirely. In such cases, ex situ conservation, which consists of preserving species outside their natural habitats, is an option via botanical and zoological gardens or gene banks (Primack, 1998; Lévêque \& Mounolou, 2003).

\section{METHODOLOGY}

This review is based mainly on published literature and personal communications. Internet publications by reputable workers were used when no peer-reviewed literature or alternate source was available.

Salinity regimes used here are modified from Schwartz (1995) as follows:

- Fresh water $=$ salinity $0-10 \mathrm{psu}$

- Brackish $=11-32$ psu

- Salt water $=>32$ psu.

Habitat categories are modified from Compagno \& Cook (1995a,b) and Last (2002) as follows:

- Marginal=common in inshore marine habitats, marginal in brackish or fresh water

- Brackish Marginal=common in brackish to freshwater habitats, marginal in rivers

- Euryhaline $=$ common in coastal marine habitats, frequently penetrating far up river beyond the influence of tidal action; may breed in fresh water

- Obligate Freshwater=occur only in fresh water.

Taxonomy follows Compagno (1999a). Ecomorphotype categories follow Compagno (1990b). Conservation status of freshwater and euryhaline elasmobranchs follows Camhi et al. (1998), Cunningham-Day (2001), and Vidthayanon (2002).

\section{RESULTS}

\section{Anthropogenic degradation of tropical freshwater and estuarine ecosystems}

The vast majority of human population is concentrated close to streams, rivers, lakes, estuaries and coastal areas (Moyle \& Leidy, 1992). In the United States, for example, some $50 \%$ of the population lives within $60 \mathrm{~km}$ of the coast and most inland cities occur on the shores of lakes and rivers (US Congress Office of Technology Assessment, 1987). In the continental United States, half of the 5.8 million $\mathrm{km}$ of rivers and streams are polluted significantly, and $360,000 \mathrm{~km}$ have been channelized to control flooding, while 75,000 sizable dams block some $98 \%$ of rivers (Carr, 1993; Palmer, 1984). As a result, 20\% of the United States' fish, $36 \%$ of its crayfish, and $55 \%$ of its mussel species are endangered or have become extinct, compared with only $7 \%$ of that nation's mammal and bird species (Master, 1990; Williams et al., 1993).

Globally, freshwater areas are probably being degraded and eliminated faster than tropical forests, which would make them the fastest disappearing major biome in the world (Myers, 1997). Due to their isolation, lakes are functionally 'ecological islands', featuring a rapid rate of speciation and high degree of endemism, resulting in exceptional biodiversity of fish faunas, especially in the tropics (Payne, 1986; Lowe-McConnell, 1987). The most widespread anthropogenic threat to estuarine ecosystems is sewage release, which often results in eutrophication and hypoxic conditions, however, many other human activities threaten estuaries, including industry, fisheries, reclamation, and recreation (Little, 2000). Mangroves play important roles in estuarine and riverine ecology, but are harvested for charcoal and cleared for aquaculture (principally shrimp) and development of shoreline real estate (Hogarth, 1999).

Fish are good indicators of trends in aquatic biodiversity because their enormous variety reflects a wide range of environmental conditions (Moyle \& Leidy, 1992). Fish also have a major impact on the distribution and abundance of other organisms in waters they inhabit (LoweMcConnell, 1987; Moyle \& Leidy, 1992; Helfman et al., 1997). Moyle \& Leidy (1992) conservatively estimated that $20 \%$ of the world's freshwater fish species $(\sim 1800$ species) are extinct or in serious decline. Evidence of serious decline in marine fish is limited largely to estuarine species, reflecting their dependence on freshwater inflows (Moyle \& Leidy, 1992). Five broad categories of proximate causes of fish biodiversity decline have been identified: (1) competition for water; (2) habitat alteration; (3) pollution; (4) introduction of exotic species; and (5) commercial exploitation (Moyle \& Leidy, 1992). Following these categories, with the addition of global climate change, mechanisms and effects of threats to freshwater and estuarine fish faunas are summarized in Table 1. Moyle \& Leidy (1992) concluded that decline in fish biodiversity typically results from multiple, cumulative, long-term effects.

The concentration of humans around freshwater systems has resulted in a much greater degree of degradation to these systems than to most open marine systems (International Institute for Environmental and Development and World Resources Institute, 1987). If the world's renewable freshwater supply is relatively constant, the average water availability per person in 1850 was about $43,000 \mathrm{~m}^{3}$ per annum; by 1990 , this figure had dropped to $9000 \mathrm{~m}^{3}$ per annum, simply due to increase in global population (Gleick, 1993). Per capita water availability and water withdrawal, by continent, show major discrepancies (Figure 2). Increasing world demand for freshwater resources generated by continued population growth, urbanization, industrialization and irrigation will likely result in further declines to freshwater biotas (Moyle \& Leidy, 1992).

\section{Biology of freshwater and euryhaline elasmobranchs}

At least 171 species of elasmobranch, representing 68 genera and 34 families, are recorded from fresh or estuarine waters (Table 2). Of these, over half (90 species) are Marginal and about one-fifth (35 species) are Obligate Freshwater. Obligate Freshwater elasmobranchs are dominated (30 species) by myliobatoid stingrays, of which twothirds (22 species) are potamotrygonid river stingrays, 
Table 1. Categories, mechanisms and effects of anthropogenic threats to freshwater and estuarine fish faunas.

\begin{tabular}{lll}
\hline Mechanism Effects & References
\end{tabular}

\section{Competition for water}

Withdrawal of surface water (for irrigation, flood control, urban \& industrial consumption)

\section{Physical habitat alteration}

Modification of bottom type

Channelization (=bank stabilization)

Dam/reservoir construction

Siltation

Deforestation

Watershed perturbation

Wetland degradation

\section{Pollution}

Municipal \& industrial point source pollution

Agricultural pollution

Acid rain

Mining

Illegal drug manufacture

Warfare

\section{Global climate change}

Combustion of fossil fuels \& wood, deforestation, cattle grazing, rice growing

\section{Commercial exploitation}

Directed fisheries

By-catch

Illegal trade in aquarium/ornamental fish

\section{Introduced species}

Introduced predators, competition, hybridization, introduced parasites \& disease, ballast water introduction

Reduction of habitat volume; increased habitat instability, extreme conditions

Moyle \& Leidy, 1992

Loss of prey habitat, loss of prey

Reduction/degradation of habitat for elasmobranchs \& prey; reduction of prey biomass

Block movement of elasmobranchs \& their prey, including cut off access to sea, extreme conditions in reservoirs, reduction in downstream nutrient \& productivity

Loss of prey spawning habitat; reduction of primary productivity; reduction of prey biomass

Rise in water temperature, decrease in dissolved oxygen; increased variation in water flow rates; loss of prey spawning \& nesting sites; siltation

Groundwater withdrawal \& contamination; reduction/ loss of riparian trees, deforestation, siltation

Reduction in nutrients; loss of prey foraging habitat \& piscine seed dispersal; reduction in prey biomass

Introduction of compounds toxic to elasmobranchs \& their prey

Introduction of compounds toxic to elasmobranchs \& their prey; feminization by organochlorines, reduction in prey biomass \& possibly in elasmobranch biomass

Water acidification; loss of prey due to direct mortality $\&$ increased reproductive failure; changes in fish community composition \& structure

Introduction of heavy metal pollutants $(\mathrm{Pb}, \mathrm{Cu}, \mathrm{Hg})$ \& radioactive isotopes toxic to elasmobranchs \& their prey; siltation

Introduction of organic chemicals (alkaloids etc.) toxic to elasmobranchs \& their prey

Introduction of petrochemical compounds \& herbicides (defoliants) toxic to elasmobranchs \& their prey; habitat modification via blasting \& mining

Increased sea level; loss of estuaries, coastal marshes, etc., loss of critical habitat for elasmobranchs and their prey; major changes in precipitation \& oceanic circulation patterns

Direct removal; overfishing, commercial or local extinction of elasmobranchs; reduction of prey base $\&$ its genetic diversity

Direct removal; reduction of prey base; changes in aquatic community composition \& structure

Direct removal; use of toxins (sodium cyanide) to collect fish; decline of native fish diversity

Population reduction or extermination of native fish, loss of prey base
Wallace \& Benke, 1984; Benke et al., 1985; Harmon et al., 1986

Simpson et al., 1982; Berger, 1992

Welcomme, 1985; Li et al., 1987

Senanayake \& Moyle, 1982;

Skelton, 1987; Moyle \&

Leidy, 1992

Goulding, 1980; Lowe-

McConnell, 1987

Helfman et al., 1997

Whigham et al., 1988

Moyle, 1976; Larsson et al., 1986; Moyle \& Leidy, 1992

Clark et al., 1985; Mearns et al., 1988

Mills \& Schindler, 1986; Schofield, 1988

Compagno \& Cook, 1995a,b

Compagno \& Cook, 1995,a,b

Compagno \& Cook, 1995,a,b

Helfman et al., 1997

Glantz \& Feingold, 1990; Smith et al., 1991

Miller et al., 1990; Nichols et al., 1990; Murray et al., 1992; Perra, 1992

Conroy et al., 1981; Derr, 1992

Taylor et al., 1984; Helfman et al., 1997 


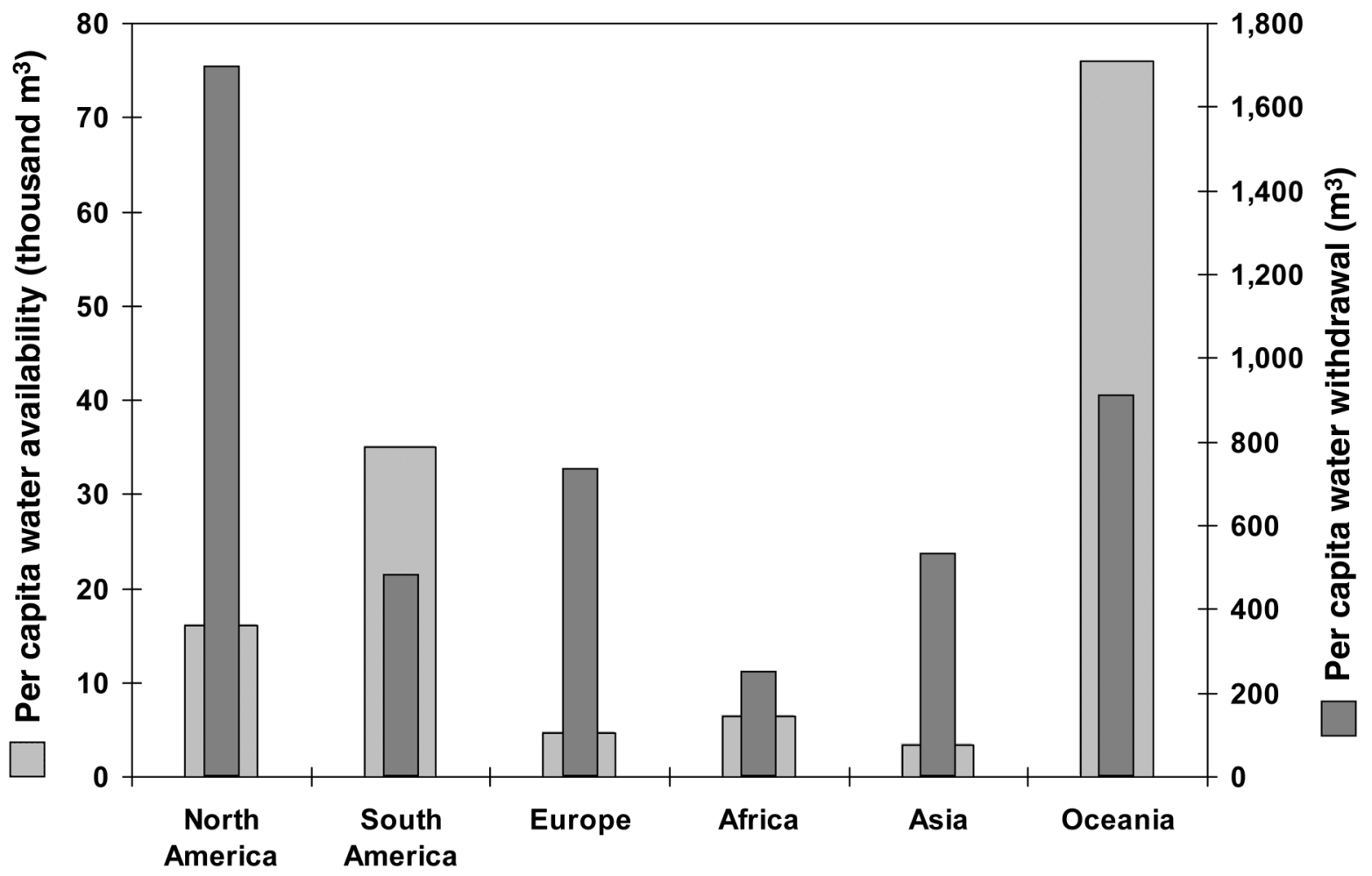

Figure 2. Discrepancies in per capita water availability versus withdrawal, by continent (data from Gleick, 1993).

endemic to Atlantic drainages of South America. Sezaki et al. (1999) found that DNA nucleotide and amino acid sequences in Indian and Thai populations of the Obligate Freshwater stingray Himantura chaophraya were clearly different, suggesting that significant evolutionary divergence occurred since their ecological isolation in different river systems. Such isolation may account for the relatively high diversity and incidence of endemism among Obligate Freshwater elasmobranchs. Of 13 Euryhaline elasmobranch species, six are pristids, six are dasyatids, and the remaining species is a carcharhinid, Carcharhinus leucas (Table 3). Carcharhinus leucas is able to withstand salinities from $<10$ to $53 \mathrm{psu}$, the latter occurring in the hypersaline St Lucia Lake system of Kwa-Zula Natal, South Africa, although it tends to move out of the lakes when salinity exceeds 50 (Bass et al., 1973). Carcharhinus leucas closely resembles the Marginal C. amboinensis, as both are shortsnouted, heavy-bodied, serrated-toothed carcharhinids (Compagno, 1984a). Off the western side of Madagascar, C. leucas is far more abundant than C. amboinensis, but the reverse is true off the eastern side; this may be the result of competitive exclusion (Bass et al., 1973). Freshwater and euryhaline elasmobranchs comprise three relatively unspecialized ecomorphotypes, rajobenthic, pristobenthic, and littoral (Compagno, 1990b), suggesting that adaptations to reduced salinity habitats are largely physiological rather than morphological.

The life history and ecology of most freshwater and euryhaline elasmobranchs are poorly known. Life history parameters for some of the better known species are presented in Table 4. In general, freshwater and euryhaline elasmobranchs adhere to strongly K-selected life histories, similar to those of their marine relatives. At least three species of Euryhaline elasmobranch breed in fresh water, the sawfish Pristis perotetti and P. microdon, and the stingray, Pastinachus sephen; the Euryhaline stingray Himantura fluviatilis may also breed in fresh water. In the Lake Nicaragua-San Juan River system, C. leucas usually gives birth near the river mouth and only rarely in the lake itself (Jensen, 1976). In contrast, Pristis perotetti copulates and usually gives birth in Lake Nicaragua, although parturition may occur in the lower San Juan River and neonates may go out to sea (Thorson, 1976a). Life history parameters of $P$. perotetti in the Lake Nicaragua-San Juan River system indicate that both sexes of this species attain smaller maximum lengths than elsewhere in its range (Thorson, 1982a). Reproduction and development of several Obligate Freshwater stingrays (Paratrygon aiereba, Plesiotrygon iwamae, Potamotrygon motoro, and P. orbignyi) have been studied in the Amazon River as well as in an aquarium (Thorson et al., 1983; Lasso et al., 1996; Charvet-Almeida, 2001). In the Brackish Marginal stingray Dasyatis guttata, parturition occurs in low salinities of $<20$, after which it disperses into and matures in fullstrength seawater (about $35 \mathrm{psu}$ ), and then restricts itself to very low salinities of $\leqslant 5$ (Thorson, 1983).

Little is known of the diet of most freshwater and euryhaline elasmobranchs. In Lake Nicaragua, C. leucas feeds heavily on teleosts (nine families, principally cichlids), but also take black land crabs (Gecarcinidae), sawfish (Pristidae), tyrant flycatchers (Tyrannidae), sloths (Bradypodidae), and a variety of non-food items (leaves, sticks, orange peelings, pebbles, corn kernels, and a glass bottle) opportunistically (Tuma, 1976). In the Cotijuba Island region of northern Brazil, the diet of three species of Obligate Freshwater potamotrygonids has recently been 
Table 2. Summary of habitat distribution of freshwater and euryhaline elasmobranchs (Modified after and updated from Compagno $\mathcal{E}^{\circ}$ Cook, 1995a).

\section{(1) MARGINAL SPEGIES: \\ Order Hexanchiformes \\ Cow sharks - family Hexanchidae Hexanchus (1 species)}

Order Squaliformes

Spiny dogfish - family Squalidae Squalus (1 species)

Order Pristiophoriformes

Saw sharks - family Pristiophoridae Pristiophorus (1 species)

Order Squatiniformes

Angel sharks - family Squatinidae Squatina (1 species)

Order Heterodontiformes

Bullhead dogfish - family

Heterodontidae

Heterodontus (1 species)

\section{Order Orectolobiformes}

Collared carpet sharks - family

Parascylliidae Parascyllium (2 species)

Blind sharks - family Brachaeluridae Brachylurus (1 species)

Heteroscyllium (1 species)

Wobbegongs - family Orectolobidae Eucrossorhinus (1 species)

Orectolobus (2 species)

Long-tailed carpet sharks - family

Hemiscylliidae Chiloscyllium (1 species)

Nurse sharks - family

Ginglymostomatidae Nebrius (1 species)

Zebra shark - family Stegostomatidae Stegostoma (1 species)

Order Lamniformes

Sand tiger sharks - family

Odontaspididae

Carcharias (1 species)

Thresher sharks - family Alopiidae Alopias (1 species)

Mackerel sharks - family Lamnidae Carcharodon (1 species)

Isurus (1 species)

Lamna (1 species)

Order Carcharhiniformes

Cat sharks - family Scyliorhinidae Asymbolus (1 species)

Haploblepharus (1 species)

Poroderma (1 species)

Schroederichthys (1 species)

Barbeled hound sharks-

Leptochariidae Leptocharias (1 species)

Hound sharks - family Triakidae Galeorhinus (1 species)

Requiem sharks - family

Carcharhinidae

Carcharhinus (12 species)

Galeocerdo (1 species)

Negaprion (2 species)

Prionace (1 species)

Rhizoprionodon (2 species)

Scoliodon (1 species)

Triaenodon (1 species)
Hammerhead sharks - family

Sphyrnidae

Sphyrna (3 species)

Order Rhiniformes

Wedgefish - family Rhinidae

Rhina (1 species)

Wedgefish - family Rhynchobatidae Rhynchobatus (3 species)

Order Rhinobatiformes

Guitarfish - family Rhinobatidae

Aptychotrema (2 species)

Rhinobatos (2 species)

Trigonorrhina (2 species)

Order Torpediniformes

Torpedo rays - family Narcinidae Narcine (1 species)

Order Rajiformes

Skates - family Rajidae

Dipturus (2 species)

Raja (1 species)

Order Myliobatiformes

Stingarees - family Urolophidae

Trigonoptera (1 species)

Urobatis (1 species)

Urolophus (4 species)

Whiptail stingrays - family Dasyatidae

Dasyatis (4 species)

Himantura (5 species)

Pteroplatytrygon (1 species)

Taeniura (2 species)

(unidentified dasyatid, North

Carolina)

Butterfly rays - family Gymnuridae Gymnura (3 species)

Eagle rays - family Myliobatidae Aetobatus (1 species) Myliobatis (1 species)

Cownose rays - family Rhinopteridae Rhinoptera (3 species)

Devil rays - family Mobulidae Manta (1 species)

\section{(2) BRAGKISH MARGINAL}

\section{SPEGIES}

\section{Order Hexanchiformes}

Cow sharks - family Hexanchidae Notorynchus (1 species)

\section{Order Squaliformes}

Dogfish sharks - family Squalidae Squalus (1 species)

Sleeper sharks - family Somniosidae Somniosus (1 species)

\section{Order Carcharhiniformes}

Cat sharks - family Scyliorhinidae Cephaloscyllium (1 species)

Hound sharks - family Triakidae Mustelus (3 species)

Triakis (1 species)

Requiem sharks - family

Carcharhinidae

Glyphis (1 species)

Negaprion (1 species)

Rhizoprionodon (1 species)

Hammerhead sharks - family

Sphyrnidae
Sphyrna (1 species)

Order Pristformes

Sawfish - family Pristidae

Pristis (1 species)

Order Rhinobatiformes

Guitarfish - family Rhinobatidae Rhinobatos (2 species)

Order Torpediniformes

Coffin rays - family Hypnidae Hypnos (1 species)

Torpedo rays - family Torpedinidae Torpedo (1 species)

Order Rajiformes

Skates-family Rajidae Okamejei (1 species) Dipturus (1 species)

Order Myliobatiformes

Stingarees - family Urolophidae Trygonoptera (2 species) Urolophus (1 species)

Whiptail stingrays - family

Dasyatidae

Dasyatis (5 species)

Himantura (2 species)

Butterfly rays - family Gymnuridae Gymnura (1 species)

Eagle rays - family Myliobatidae Myliobatis (2 species)

Cownose rays - family Rhinopteridae Rhinoptera (1 species)

(3) EURYHALINE SPEGIES:

Order Carcharhiniformes

Requiem sharks - family

Carcharhinidae Carcharhinus (1 species) Glyphis (2 species)

Order Pristiformes

Sawfish-family Pristidae Anoxypristis (1 species) Pristis (5 species)

Order Myliobatiformes

Whiptail stingrays - family

Dasyatidae
Dasyatis (3 species)
Himantura (1 species)
Pastinachus (1 species)
Urogymnus (1 species)

\section{(4) OBLIGATE FRESHWATER SPECIES:}

Order Carcharhiniformes

Requiem sharks - family

Carcharhinidae Glyphis (3 species)

Order Myliobatiformes

River stingrays - family

Potamotrygonidae Paratrygon (1 species) Plesiotrygon (1 species) Potamotrygon (19 species) (undescribed potamotrygonid)

Whiptail stingrays - family Dasyatidae Dasyatis (3 species)

Himantura (5 species) 
Table 3. Species diversity of freshwater and euryhaline elasmobranchs by order and habitat type.

\begin{tabular}{|c|c|c|c|c|c|}
\hline Order & Brackish Marginal & Marginal & Euryhaline & Obligate & Total \\
\hline Hexanchiformes & 1 & 1 & & & 2 \\
\hline Squaliformes & 2 & 1 & & & 3 \\
\hline Pristiophoriformes & & 1 & & & 1 \\
\hline Squatiniformes & & 1 & & & 1 \\
\hline Heterodontiformes & & 1 & & & 1 \\
\hline Orectolobiformes & & 10 & & & 10 \\
\hline Lamniformes & & 5 & & & 5 \\
\hline Carcharhiniformes & 9 & 28 & 3 & 3 & 43 \\
\hline Pristiformes & 1 & & 6 & & 7 \\
\hline Rhiniformes & & 4 & & & 4 \\
\hline Rhinobatiformes & 2 & 6 & & & 8 \\
\hline Torpediniformes & 2 & 1 & & & 3 \\
\hline Rajiformes & 2 & 3 & & & 5 \\
\hline Myliobatiformes & 14 & 28 & 6 & 31 & 78 \\
\hline Total & 33 & 91 & 13 & 36 & 171 \\
\hline
\end{tabular}

investigated. Potamotrygon orbignyi feeds primarily on sphaeromatid water lice, and chironomid insect larvae, $P$. scobina also feeds primarily on sphaeromatids but also takes palaemonid shrimps, while Pleisiotrygon iwamae feeds almost exclusively on palaemonids but also consumes significant quantities of vegetable matter (Bragança et al., 2004). On the Caribbean coasts of Costa Rica, Colombia, and Venezuela, Thorson (1983) found that D. guttata feeds on small teleosts (including a 9-mm Tarpon atlanticus larva) and molluscs (gastropods, bivalves), taking small quantities of plant fragments and concluded this species is ecologically equivalent to its Euryhaline congener D. sabina.

Distribution of freshwater and euryhaline elasmobranchs is biased toward those developed nations that have active marine research programmes, but diversity appears concentrated in those areas with the largest human populations (Figure 3). Between 1976 and 1997, Japanese research teams undertook field surveys of freshwater elasmobranchs at 12 remote sites scattered throughout south-east Asia, Central and South America, West Africa, and Oceania, collecting and examining over 200 specimens representing 16 species (see Taniuchi, 2002 for review). Compagno \& Roberts (1982) reported three species of dasyatid stingrays from south-east Asia and New Guinea, describing a new species (Himatura signifier) and presenting evidence of two unidentified species. Roberts \& Karnasuta (1987) described a new dasyatid (Dasyatis laosensis) from the Mekong River of Laos and Thailand. An undescribed Dasyatis sp., distinct from D. laosensis but which has long been confused with D. akajei, occurs $1200 \mathrm{~km}$ up the Zhu River, in the Guanggion Distict of China, making it the northernmost freshwater stingray (Ishihara et al., 2005; H. Ishihara, Taiyo Engineering, Kyobashi, Chuoh-ku, Japan, personal communication). Monkolprasit \& Roberts (1990) described a new, giant dasyatid stingray (Himantura chaophraya) from several freshwater rivers in Thailand. Most of these regions are categorized as 'least developed' and feature rapidly growing human populations, with least developed parts of Asia's population more than doubling between 1960 and 1990 (Compagno \& Cook, 1995a). As described above, such burgeoning populations exert multitudinous and ever increasing stresses on the freshwater and estuarine habitats exploited by elasmobranchs. The conservation status of selected freshwater and euryhaline elasmobranchs is presented in Table 5. Knowledge of the distribution, life history, ecology, and conservation status of freshwater and euryhaline elasmobranchs is frustrated by numerous taxonomic problems, some of the more outstanding of which are summarized in Table 6.

\section{Case history: Glyphis spp.}

Sharks of the genus Glyphis are among the least known of elasmobranchs. There are at least six species of Glyphis, of which half are inadequately described and the other half completely undescribed. The stuffed holotype of G. gangeticus, a $178-\mathrm{cm}$ late adolescent or adult male reputedly collected $100 \mathrm{~km}$ up the Ganges River, was deposited in the Zoologishes Museum, Humboldt Universitat, Berlin; it was lost and feared destroyed during WWII, but was re-located in 1988 (Compagno, 1984a, 2002). However, Roberts (2005; T.R. Roberts, Research Associate, Smithsonian Tropical Research Institute, Panama, personal communication) re-examined the original type locality data and concluded it had long been misinterpreted: the holotype was apparently collected in the lower Sundarbans, south of Kulna, in a strongly tidal, brackish area quite near the sea; he reports collecting or observing numerous specimens from marine habitats off Bangladesh and Myanmar. The single remaining syntype of G. gangeticus, a $56-\mathrm{cm}$ alcohol preserved neonate, is in the ichthyological collections of the Muséum National d'Histoire Naturelle, Paris (catalogue no. NMNH 1144). The only other known museum specimen is a $61-\mathrm{cm}$ female neonate collected in April 1967 in the Hooghly River, preserved in alcohol, and discovered serendipitously in the collections of the Zoological Survey of India, Calcutta (catalogue no. ZSI 8067), where it was mislabelled 'Carcharhinus temmincki' (Compagno, 1984b, 1987). However, after an extensive 10-year search, a few specimens were caught in 1996 in the Ganges River (Compagno, 2002). Glyphis gangeticus has a hideous 
Table 4. Life history parameters for some of the better known euryhaline and obligate freshwater elasmobranchs.

\begin{tabular}{|c|c|c|c|c|c|c|c|}
\hline Species & $\begin{array}{l}\text { Age (Maturity, } \\
\text { Longevity, } \\
\mathrm{M} / \mathrm{F})\end{array}$ & $\begin{array}{l}\text { Size }(\mathrm{cm}) \\
\text { (Birth, Maturity, } \\
\text { Maximum) }\end{array}$ & $\begin{array}{l}\text { Gestation Time } \\
\text { (months) Litter Size } \\
\text { (pups) }\end{array}$ & e Distribution & $\begin{array}{l}\text { Pelagic/ Demersal Habitat } \\
\text { Pupping/ Nursery Grounds }\end{array}$ & $\begin{array}{l}\text { Fisheries } \\
\text { Pressure } \\
\text { (Directed, } \\
\text { Incidental) }\end{array}$ & References \\
\hline \multicolumn{8}{|l|}{ Euryhaline } \\
\hline Carcharhinus leucas & $\begin{array}{l}\text { Mat: } 6-8 \text { or } 15 \\
\mathrm{~L}(\mathrm{M}) 16 \\
\mathrm{~L}(\mathrm{~F}) 12 \text { to } 27\end{array}$ & $\begin{array}{c}\text { B: } 56-81 \\
\text { Mat: } 200 \\
\text { Max: } 300-320\end{array}$ & $\begin{array}{l}\text { G: } 10 \text { to } 11 \\
\text { LS: } 1 \text { to } 13\end{array}$ & $\begin{array}{l}\text { Wide-ranging in tropical to } \\
\text { subtropical waters }\end{array}$ & $\begin{array}{l}\text { Pelagic } \\
\text { H: Coastal into estuaries and freshwater } \\
\text { P/NG: Estuarine }\end{array}$ & $\begin{array}{l}\text { D: High } \\
\text { I: High }\end{array}$ & $\begin{array}{l}\text { Branstetter \& Stiles, 1987; Camhi et } \\
\text { al., } 1998\end{array}$ \\
\hline Glyphis gangeticus & & $\begin{array}{l}\text { B: } 56-61 \\
\text { Mat: } 178 \\
\text { Max: } 204\end{array}$ & & & & & $\begin{array}{l}\text { Compagno, 1987; Camhi et al., } \\
1998\end{array}$ \\
\hline Pristis microdon & $\mathrm{L}(\mathrm{M}) 44$ & Max: 700 & & Localized in tropics & $\begin{array}{l}\text { Demersal } \\
\text { H: Freshwater }\end{array}$ & $\begin{array}{l}\text { D: High } \\
\text { I: High }\end{array}$ & $\begin{array}{l}\text { Tanaka, 1991; Last \& Stevens, } \\
\text { 1994; Compagno \& Cook, 1995a }\end{array}$ \\
\hline Pristis pectinata & $\begin{array}{l}\text { Mat: } 10 \\
\mathrm{~L}(\mathrm{M}) 30 \\
\mathrm{~L}(\mathrm{~F}) 30\end{array}$ & $\begin{array}{c}\text { B: } 60 \\
\text { Max: } 760\end{array}$ & $15-20$ & Wide-ranging, disjunct & $\begin{array}{l}\text { Demersal } \\
\text { H: Coastal and freshwater } \\
\text { P/NG: Shallow bays and estuaries }\end{array}$ & $\begin{array}{l}\text { D: High } \\
\text { I: High }\end{array}$ & $\begin{array}{l}\text { Bigelow \& Schroeder, 1953; Camhi } \\
\text { et al., 1998; Simpfendorfer, } 2000\end{array}$ \\
\hline Pristis perotteti & $\begin{array}{l}\text { Mat: } 10 \\
\mathrm{~L}(\mathrm{M}) 30\end{array}$ & & & & & & Simpfendorfer, 2000 \\
\hline Pristis zijsron & & $\begin{array}{l}\text { Mat: } 430 \\
\text { Max: } 730\end{array}$ & & & $\begin{array}{l}\text { Demersal } \\
\text { H: Coastal into estuaries and freshwater }\end{array}$ & $\begin{array}{l}\text { D: Low } \\
\text { I: High }\end{array}$ & Last \& Stevens, 1994 \\
\hline Dasyatis fluviorum & & $\begin{array}{c}\text { B: } 11 \\
\text { Max: } 120\end{array}$ & & & & $\begin{array}{l}\text { D: Low } \\
\text { I: Moderate-high }\end{array}$ & $\begin{array}{l}\text { Last \& Stevens, 1994; Cavanagh et } \\
\quad \text { al., } 2003\end{array}$ \\
\hline Dasyatis sabina & & $\begin{array}{c}\text { B: } 10 \\
\text { Max: } 91\end{array}$ & & $\begin{array}{l}\text { western North Atlantic, } \\
\text { temperate - sub tropical }\end{array}$ & $\begin{array}{l}\text { Demersal } \\
\text { H: Coastal into estuaries and freshwater }\end{array}$ & $\begin{array}{l}\text { D: Low } \\
\text { I: Moderate }\end{array}$ & Murdy et al.,1997; Michael, 1993 \\
\hline Urogymnus ukpam & & Max: 140 & & & & & Compagno \& Cook, 1995a \\
\hline Himantura uarnak & & $\begin{array}{l}\text { B: } 20-40 \\
\text { Max: } 200\end{array}$ & $\begin{array}{l}\text { G: } 12 \\
\text { LS: } 1-5\end{array}$ & widespread Indo-West Pacific & $\begin{array}{l}\text { Demersal } \\
\text { H: Coastal into estuaries and freshwater }\end{array}$ & $\begin{array}{l}\text { D: Low } \\
\text { I: Low }\end{array}$ & $\begin{array}{l}\text { Michael, 1993; Last \& Stevens, } \\
1994\end{array}$ \\
\hline Pastinachus sephen & $\begin{array}{l}\text { Mat: } 4 \text { to } 6 \\
\mathrm{~L}(\mathrm{M}) 7\end{array}$ & $\begin{array}{c}\text { B: } 18 \\
\text { Max: } 180\end{array}$ & & Indo-West Pacific & $\begin{array}{l}\text { Demersal } \\
\text { H: Coastal into estuaries and freshwater }\end{array}$ & D: Low & $\begin{array}{l}\text { Last \& Stevens, 1994; Tanaka \& } \\
\quad \text { Ohnishi, } 1998\end{array}$ \\
\hline \multicolumn{8}{|l|}{ Obligate } \\
\hline Glyphis species B & & & ? & $\begin{array}{l}\text { Localized; restricted to rivers } \\
\text { in Borneo? }\end{array}$ & $\begin{array}{l}\text { Demersal } \\
\text { H: Freshwater-estuarine } \\
\text { P/NG: Freshwater-estuarine }\end{array}$ & $\begin{array}{l}\text { D: Low } \\
\text { I: Low-moderate } \\
\text { (by-catch) }\end{array}$ & Camhi et al., 1998 \\
\hline Potamotrygon motoro & & Mat: $39-44$ & 6 to 11 & & & & Thorson et al., 1983 \\
\hline $\begin{array}{l}\text { Dasyatis laosensis } \\
\text { Himantura chaophraya }\end{array}$ & $\begin{array}{l}\text { Mat: } 1 \text { to } 4 \\
\text { Mat: }<7\end{array}$ & $\begin{array}{l}\text { B: } 30-33 \\
\text { Mat: } 110 \\
\text { Max: } 200\end{array}$ & 4 to 6 & Localized & $\begin{array}{l}\text { Demersal } \\
\text { H: Freshwater-estuarine } \\
\text { P/NG: Freshwater }\end{array}$ & $\begin{array}{l}\text { D: Moderate } \\
\text { I: Moderate }\end{array}$ & $\begin{array}{l}\text { Compagno \& Cook, 1995a } \\
\text { Last \& Stevens, 1994; Compagno \& } \\
\text { Cook, 1995a,d; Cavanagh et al., } \\
2003\end{array}$ \\
\hline Himantura signifer & $\begin{array}{l}\text { Mat: } 1 \text { to } 3 \\
\text { L(M) } 5 \\
\mathrm{~L}(\mathrm{~F}) 5\end{array}$ & B: $15-35$ & & & $\begin{array}{l}\text { H: Freshwater } \\
\text { P/NG: Freshwater }\end{array}$ & & Last \& Stevens, 1994; \\
\hline
\end{tabular}




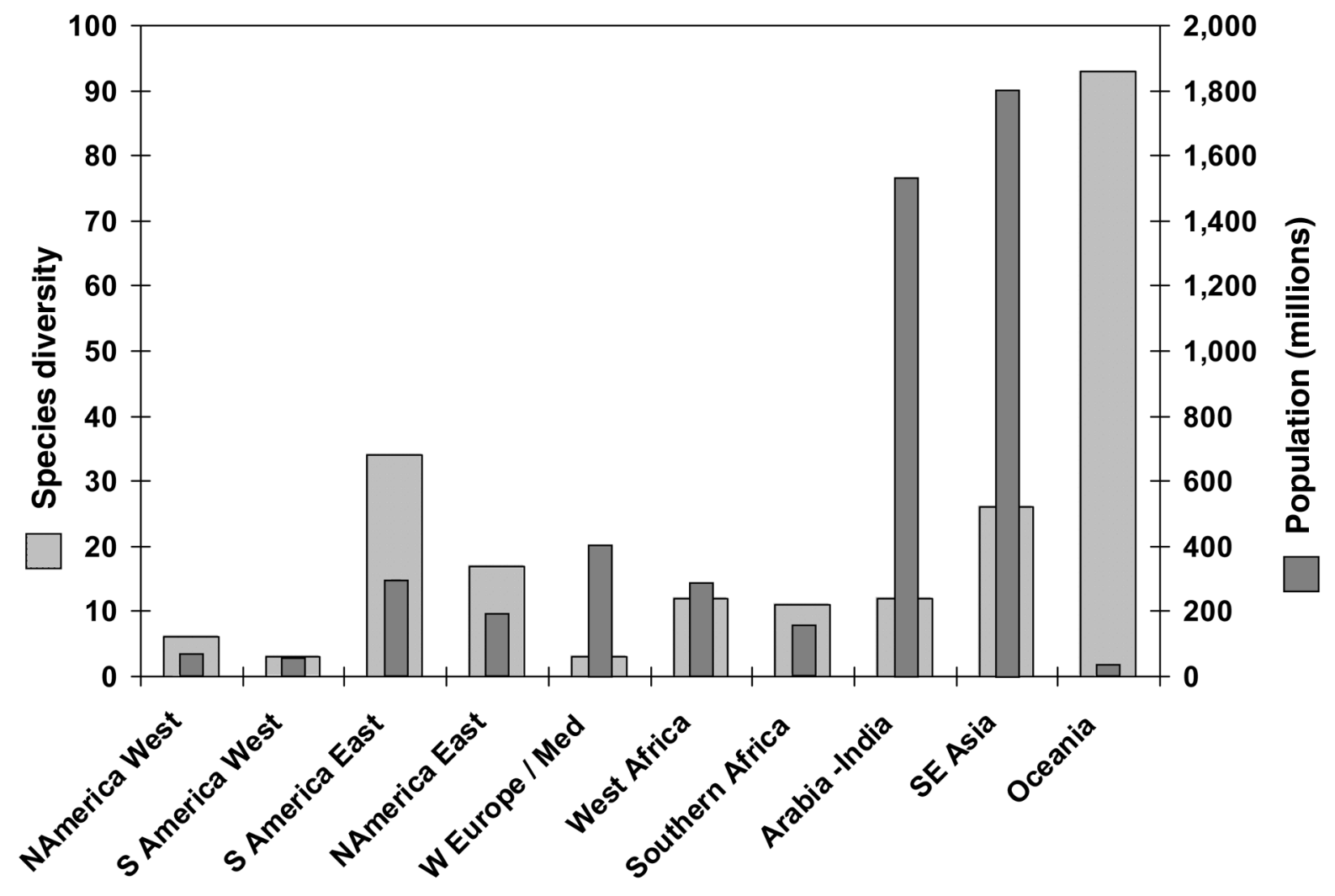

Figure 3. Species diversity of freshwater and euryhaline elasmobranchs versus coastal human population, by broad geographic region (population data from Brunner, 2005).

reputation as a man-eater, probably largely due to confusion with Carcharhinus leucas, which occurs with it in the Hooghly River and probably in the Ganges River as well (Compagno, 1984a). Glyphis glyphis, vernacularly known as the speartooth shark in reference to its hastate lower anterior dentition, is known only from the $100-\mathrm{cm}$ stuffed holotype in the collections of the Zoologishes Museum; its type locality is not recorded (Compagno, 1984a). Glyphis siamensis was originally described by Steindachner in 1896 as Prionodon siamensis, based on a 63-cm specimen from the Irrawaddy River near Rangoon, Burma; the holotype is in the Naturhistorishes Museum, Vienna (Compagno, 1988). The Glyphis species $\mathrm{A}$ is known from two $70-\mathrm{cm}$ juvenile specimens taken in 1982 from $17 \mathrm{~km}$ up the Bizant River, Queensland, Australia (Last \& Stevens, 1994; Last, 2002). Glyphis species B is known from the holotype from 'Borneo' (no further information recorded) in the Naturhistorishes Museum; several small Glyphis sharks were collected from the Kinabatangan River, Borneo, between December 1996 and March 1997, but it remains to be seen whether they are conspecific with Glyphis species B (Compagno, 2002; Manjaji, 2002). An undescribed Glyphis is known from two juvenile specimens examined by J.A.F. Garrick but subsequently destroyed and five sets of jaws with little data from Port Romilly, Bainuru, and the upper reaches of the Fly River, Papua New Guinea (Compagno, 1988, 2002). It may be conspecific with Glyphis species C of the Northern Territory, Australia, which is known from nine specimens from the Adelaide River and East, West and South Alligator Rivers, including an immature female taken $100 \mathrm{~km}$ up the Adelaide River and a $145-\mathrm{cm}$ adult male taken some $60 \mathrm{~km}$ up the South Alligator River (Larson, 2000; Compagno, 2002; Last, 2002). Another similar shark was caught about $60 \mathrm{~km}$ from the mouth of the South Alligator River; although the jaws were saved and the shark photographed, the specimen was eaten by the angler who caught it (Compagno, 2002). Recently, seven specimens of Glyphis species C were collected from macrotidal mangrove swamps near Darby, in the Kimberley region of Western Australia (Thorburn \& Morgan, 2004). Of all Glyphis sharks, Glyphis species C most closely resembles $G$. glyphis in its dentition, but further examination is needed to test this (Compagno, 2002). Presently, Glyphis sharks are most readily differentiated on the basis of tooth and vertebral counts (Table 7).

Most aspects of the biology and ecology of river sharks are virtually unknown. Knowledge of the biology and distribution of Glyphis sharks is frustrated by confusion with C. leucas (Larson, 2000; Compagno, 2002; Pogonoski et al., 2002). The relatively small eyes and teeth of Glyphis sharks and their well developed ampullae of Lorenzini suggest that they are primarily piscivores that have adapted to hunting in turbid estuarine and riverine waters (Compagno, 1987; Thorburn \& Morgan, 2004). Glyphis species C from macrotidal mangrove systems of the Kimberley region of Western Australia contained remains of the teleosts Arius graeffei and Polydactylus macrochir (Thorburn \& Morgan, 2004). Given the limited visibility of many tropical rivers and estuaries, it seems likely that mechanoreception, olfaction, and electroreception may play a more significant role in predation 
Table 5. IUCN conservation status of selected freshwater and euryhaline elasmobranchs, organized by salinity categories. Data from the 2004 IUCN Red List (Baillie et al., 2004).

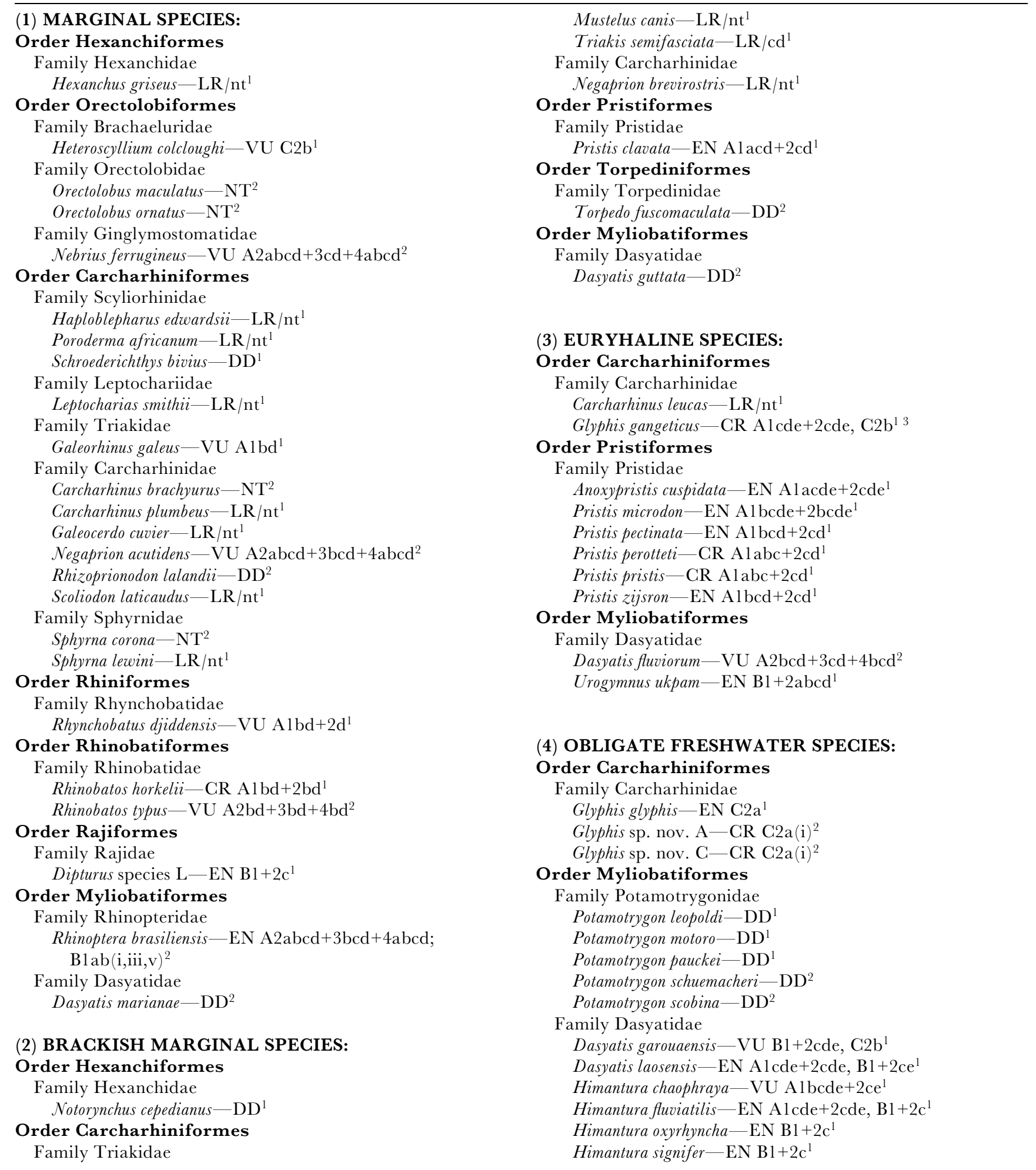

LR, Lower Risk; VU, Vulnerable; NT, Near Threatened; En, Endangered; CR, Critically Endangered; DD, Data Deficient.

1, ver 2.3 (1994); ${ }^{2}$, ver 3.1 (2001); ${ }^{3}$, IUCN status is based on presumption this species is rare and Obligate Freshwater (see Compagno, 1997); however, Roberts (2005) contends Glyphis gangeticus is the most common large carcharhinid in marine waters of the Bay of Bengal, that there is no evidence of historical decline in the species' range or population, and that it is neither critically endangered nor particularly threatened.

than vision. The eyes of $G$. gangeticus are tilted dorsally rather than laterally or ventrally, as in most carcharhinids, suggesting that this species may swim along the bottom and scan the water above it for potential prey back-lit by the sun (Compagno, 1984b). However, Roberts (2005) reports that $G$. gangeticus in the Bay of Bengal feed heavily on dasyatid stingrays, which spend much of their time on the bottom.

Like other carcharhinids (except the tiger shark, Galeocerdo cuvier, which appears to be secondarily 
Table 6. Taxonomic problems of freshwater and euryhaline elasmobranchs.

\begin{tabular}{ll}
\hline Taxon & Problem(s) \\
\hline Carcharhinus & Paraphyletic \\
Glyphis & 3+ undescribed species \\
Glyphis siamensis \& G. species A & May by synonymous with $G$. gangeticus \\
Lamiopsis & May be junior synonym of Glyphis \\
Pristidae & Systematics highly unsettled; lack of curated whole adult specimens \\
Neotropical Dasyatis & Paraphyletic \\
Dasyatis brevis & Junior synonym of $D$. diptura \\
Dasyatis sp. (China) & May be synonymous with $D$. laosensis \\
Himantura & Paraphyletic \\
Himantura fluviatilis complex & 3 species may be synonymous \\
Himantura krempfi & May be synonymous with $H$. oxyrhyncha \\
Aetobatus narinari & Appears to be a complex of 4 species \\
Potamotrygonidae & 5+ undescribed species; many species inadequately defined; high degree of intraspecific \\
& polychromatism \\
Potamotrygon dumerilii and $P$. humerosa & Inadequately defined; lack material for proper characterisation \\
\hline
\end{tabular}

Table 7. Features useful for identifying sharks of the genus Glyphis. Data compiled from Last \& Stevens (1994); Compagno \&8 Neim (1998); Thorburn \& Morgan (2004); Compagno et al. (2005).

\begin{tabular}{|c|c|c|c|c|c|c|c|}
\hline Species & $\begin{array}{l}\text { Head Shape } \\
\text { in Lateral } \\
\text { View }\end{array}$ & $\begin{array}{l}\text { Total Tooth } \\
\text { Count }\end{array}$ & Lower Anterior Teeth & $\begin{array}{l}\text { Total } \\
\text { Vertebral } \\
\text { Count }\end{array}$ & $\begin{array}{l}\text { Free Rear Tip } \\
\text { of First } \\
\text { Dorsal Fin }\end{array}$ & $\begin{array}{l}\text { Second Dorsal } \\
\text { Fin Height }\end{array}$ & Fin Markings \\
\hline $\begin{array}{l}\text { Glyphis } \\
\text { gangeticus }\end{array}$ & $\begin{array}{l}\text { High and } \\
\text { broad }\end{array}$ & $30-37 / 31-34$ & $\begin{array}{l}\text { Weakly serrated, } \\
\text { non-hastate, } \\
\text { low basal cusplets }\end{array}$ & 169 & $\begin{array}{l}\text { Anterior to } \\
\text { pelvic fin origin }\end{array}$ & $\begin{array}{l}1 / 2 \text { that of first } \\
\text { dorsal fin }\end{array}$ & $\begin{array}{l}\text { All fins plain, without dusky } \\
\text { margins }\end{array}$ \\
\hline Glyphis glyphis & $\begin{array}{l}\text { High and } \\
\text { broad }\end{array}$ & $26-29 / 27-29$ & $\begin{array}{l}\text { Serrate tips, hastate, } \\
\text { no basal cusplets }\end{array}$ & $?$ & $\begin{array}{l}\text { Anterior to } \\
\text { pelvic fin origin }\end{array}$ & $\begin{array}{l}3 / 5 \text { that of first } \\
\text { dorsal fin }\end{array}$ & $\begin{array}{l}\text { All fins plain, without dusky } \\
\text { margins }\end{array}$ \\
\hline $\begin{array}{l}\text { Glyphis } \\
\text { siamensis }\end{array}$ & $\begin{array}{l}\text { High and } \\
\text { broad }\end{array}$ & $29 / 29$ & $\begin{array}{l}\text { Weakly serrated, low } \\
\text { basal cusplets }\end{array}$ & 209 & $\begin{array}{l}\text { Anterior to } \\
\text { pelvic fin origin }\end{array}$ & $\begin{array}{l}1 / 2 \text { that of first } \\
\text { dorsal fin }\end{array}$ & $\begin{array}{l}\text { All fins plain, without dusky } \\
\text { margins }\end{array}$ \\
\hline $\begin{array}{l}\text { Glyphis } \\
\text { species A }\end{array}$ & $\begin{array}{l}\text { High and } \\
\text { broad }\end{array}$ & $33-55 / 32-55$ & $\begin{array}{l}\text { Unserrated, tips } \\
\text { hastate, low basal } \\
\text { cusplets }\end{array}$ & $148-217$ & $\begin{array}{l}\text { Opposite } \\
\text { pelvic fin origin }\end{array}$ & $\begin{array}{l}3 / 5 \text { that of first } \\
\text { dorsal fin }\end{array}$ & $\begin{array}{l}\text { All fins with black or dusky } \\
\text { edges }\end{array}$ \\
\hline $\begin{array}{l}\text { Glyphis } \\
\text { species B }\end{array}$ & $\begin{array}{l}\text { High and } \\
\text { broad }\end{array}$ & $28-31 / 29-32$ & $\begin{array}{l}\text { Weakly serrated, non- } \\
\text { hastate, low basal } \\
\text { cusplets }\end{array}$ & $196-205$ & $\begin{array}{l}\text { Anterior to } \\
\text { pelvic fin origin }\end{array}$ & $\begin{array}{l}3 / 5 \text { that of first } \\
\text { dorsal fin }\end{array}$ & $\begin{array}{l}\text { Fins plain and light, except } \\
\text { for dark patch on pectoral } \\
\text { bases and dusky tip on } \\
\text { hypocaudal lobe }\end{array}$ \\
\hline $\begin{array}{l}\text { Glyphis } \\
\text { species C }\end{array}$ & $\begin{array}{l}\text { Flat and } \\
\text { narrow }\end{array}$ & $32-34 / 32-34$ & $\begin{array}{l}\text { Non-hastate, } \\
\text { no basal cusplets }\end{array}$ & $140-151$ & $\begin{array}{l}\text { Opposite pelvic } \\
\text { fin origin }\end{array}$ & $\begin{array}{l}3 / 5 \text { that of first } \\
\text { dorsal fin }\end{array}$ & $\begin{array}{l}\text { All fins plain, without dusky } \\
\text { margins }\end{array}$ \\
\hline
\end{tabular}

aplacentally viviparous), river sharks are probably placentally viviparous (Compagno, 1984a, 1988). No data are available on litter size or gestation. A $178-\mathrm{cm}$ male specimen of Glyphis gangeticus was apparently mature and late foetuses or neonates are 56-61 cm long (Compagno, 1984a, 1997). A 142-cm male specimen of Glyphis species C was apparently mature (Thorburn \& Morgan, 2004). Glyphis sharks may reach a maximum length of $200 \mathrm{~cm}$ or more (Compagno, 2002; Last, 2002). All Glyphis sharks appear able to tolerate low or reduced salinity environments. Historically, G. gangeticus is known only from fresh water, but it apparently occurs in brackish and marine water as well (Compagno, 1997; Roberts, 2005; T.R. Roberts, personal communication). The confused identity and lack of type locality of $G$. glyphis preclude any factual statement about its preferred habitat (Compagno, 1984a); it is here regarded as an inshore estuarine and possibly freshwater species. Glyphis siamenisi, known only from the holotype, appears to have been caught in fresh water (Compagno, 1988). Compagno (1999a) regards
G. siamensis as valid but Roberts (2005) contends that this species is a junior synonym of $G$. gangeticus; further work is needed to resolve this matter. Glyphis species A is known from possibly brackish waters east of the Queensland divide, where it occurs alongside the bull shark (Compagno, 2002; Last, 2002). All records of Glyphis species B are from fresh water, but it may prove to enter brackish or even full strength seawater (Compagno, 2002; Manjaji, 2002). Glyphis species C is known from fresh to full-strength seawater with salinities ranging from 6 to 36.6 (Larson, 2000; Thorburn et al., 2003). Tanaka (1991) estimated that a $130-\mathrm{cm}$ female Glyphis species C from the Adelaide River was four years old, based on growth rings in the vertebral centra. Glyphis species C is apparently sympatric with Glyphis species A, C. leucas, and C. amboinensis in the Alligator River system (Larson, 2000). Although Compagno \& Cook (1995a) provisionally classified Glyphis sharks as Marginal, they are probably more dependent on riverine habitats than previously supposed (Compagno, 2002; Last, 2002). 
Glyphis gangeticus is listed as critically endangered and G. glyphis as endangered on the IUCN International Red List (Cunningham-Day, 2001). However, Roberts (2005; personal communication) contends that $G$. gangeticus is the most common large carcharhinid in the Bay of Bengal, that there is no evidence of historical decline in the species' range or population, and that it is neither critically endangered nor particularly threatened. Glyphis species A is listed as critically endangered and Glyphis species $\mathrm{C}$ is listed as endangered under Australia's Environmental Protection and Biodiversity Act 1999 (Pogonoski et al., 2002). Both species were recently assessed by the IUSN Shark Specialist Group as critically endangered (Cavanagh et al., 2003). Glyphis species C may already be extinct in the Bizant River, although it may still exist in larger rivers nearby (Last, 2002). Thorburn \& Morgan (2004) report a high incidence of fused vertebrae and spinal deformation in Western Australian representatives of this species, which may indicate a small gene pool in this population.

\section{Case history: Pristidae}

As a group, pristids are among the most easily recognizable of elasmobranchs. Yet their taxonomy is chaotic and their phyletic diversity unresolved (Compagno \& Cook, 1995a). Two well-defined genera are recognized, Anoxypristis (characterized by a lack of rostral teeth along the posterior quarter of the saw, narrow pectoral fin bases, and a strongly forked caudal fin with lower lobe more than half the length of the upper), and Pristis (with rostral teeth along the full length of the saw, broad pectoral fin bases, and a weakly forked or unforked caudal fin with lower lobe much less than half the length of the upper), but how they are interrelated is unclear (Last \& Stevens, 1994; Compagno \& Cook, 1995a). Anoxypristis is monotypical and Pristis contains between three and eight nominal species that are separable into two groups: (1) Pristis pristis complex (characterized by a relatively broad-based, strongly tapered, robust saw typically with 15-22 large rostral teeth on either side), which may contain only a single valid species, $P$. pristis, or as many as five, P. leichhardti, P. microdon, P. perotetti, P. pristis, P. zephyreus; and (2) Pristis pectinata complex (characterized by a relatively narrow based, weakly tapered, gracile saw typically with 23-35 small rostral teeth on either side), which may contain three species, P. clavata, P. pectinata, and P. zijsron (Compagno \& Cook, 1995a; Zorzi, 1995). This systematic arrangement is supported fully by comparative dermal denticle morphology (Deynat, 2005). However, full resolution of these taxonomic problems will require examination of whole adults from throughout the range of each nominal species and/or molecular genetic sampling; unfortunately most museum collections include only dried saws, preserved heads or whole juvenile specimens (Compagno \& Cook, 1995a; Zorzi, 1995). Compagno (1999a) recognized six species of Pristis, a scheme which is here followed provisionally.

Pristids are tropical inshore marine and freshwater batoids that are conspicuous for their rostral saws and large size, with some individuals reputedly reaching total lengths of $760 \mathrm{~cm}$ or more (Last \& Stevens, 1994; Compagno \& Cook, 1995a). Historical records of pristids in fresh water are reviewed by Zorzi (1995) and their present distribution in freshwater rivers and lakes is surveyed by Compagno \& Cook (1995a). The reproductive biology, life history, and diet of most pristid species are poorly known. Development in pristids is believed to be aplacentally viviparous (Compagno, 1999b). During embryonic development, the saw and rostral teeth of P. pectinata and $P$. perotetti are soft and flexible, enclosed in a membrane until birth (Bigelow \& Schroeder, 1953; Miller, 1995). Gravid P. pectinata have been found with 15-20 embryos (Bigelow \& Schroeder, 1953). Studies of P. perotetti in Lake Nicaragua report age at maturity of $\sim 10 \mathrm{y}$, a gestation of approximately five months, length at birth of about $76 \mathrm{~cm}$, and litters of $1-13$ pups (mean 7.3 pups), with individual females likely giving birth in alternate years (Thorson, 1976a, 1982a). Pristis pectinata pups are roughly $60 \mathrm{~cm}$ long at birth, but further data on age and growth of this species are not available (Bigelow \& Schroeder, 1953). An $87-\mathrm{cm}$ Pristis microdon with a healed vitelline scar was recently captured in freshwater reaches of the Wearyan River, in the Northern Territory of Australia (Thorburn et al., 2003). Length-frequency aging and maturity data indicate that the Fitzroy River, in tropical Western Australia, is an important nursery area for P. microdon, juveniles of which appear to remain in the river for four to five years before leaving it to mature (Thorburn et al., 2004a).

The pristid rostral saw serves as both a food-gathering device and a defensive weapon. Pristis pectinata uses its rostral saw to sift through bottom sediment in search of buried prey, dig out crabs and other invertebrates from the bottom, as well as kill or maim mugilids and other small, slow-swimming schooling teleosts in the water column via lateral, scythe-like sweeps of its saw; prey impaled on the rostral teeth are removed by violent lateral shakes of the head (Breeder, 1952; Bigelow \& Schroeder, 1953; van der Elst, 1988; Compagno et al., 1989). All pristids feature huge occipital condyles, a collar on the anterior face of the synarcual that fits into the foramen magnum and protects the spinal cord, and an antorbitopectoral muscle on each side that attaches from the antorbital cartilage to the propterygium; this arrangement may help control the motion of the heavy rostrum and neurocranium relative to the synarcual, the rest of the head, and the body when a sawfish swings its saw horizontally (Compagno, 1977). There is a report (Lal Mohan, 1986) of a pristid killing a dugong (Dugong dugon) and numerous reports of people being seriously injured or killed by sawfish (Day, 1878; Verrill, 1948; McCormick et al., 1963; Helm, 1976; Edmonds, 1989). Although pristids are generally unaggressive toward humans, a large individual is a powerful animal that often thrashes vigorously when tangled in a net, making it difficult and highly dangerous to remove (Last \& Stevens, 1994).

Habitat requirements of pristids are poorly known. Recent work in northern Australia suggests that sympatric pristid species may be ecologically separated by very precise habitat preferences. In this region, $P$. microdon is caught mostly at salinities $<10$ in clear waters with high dissolved $\mathrm{O}_{2}$ content, $P$. clavata and $P$. zijsron are caught mostly at salinities of about 30-40, but the former seems to prefer slow moving, highly turbid waters with low dissolved $\mathrm{O}_{2}$ content while the latter seems to prefer tidal 


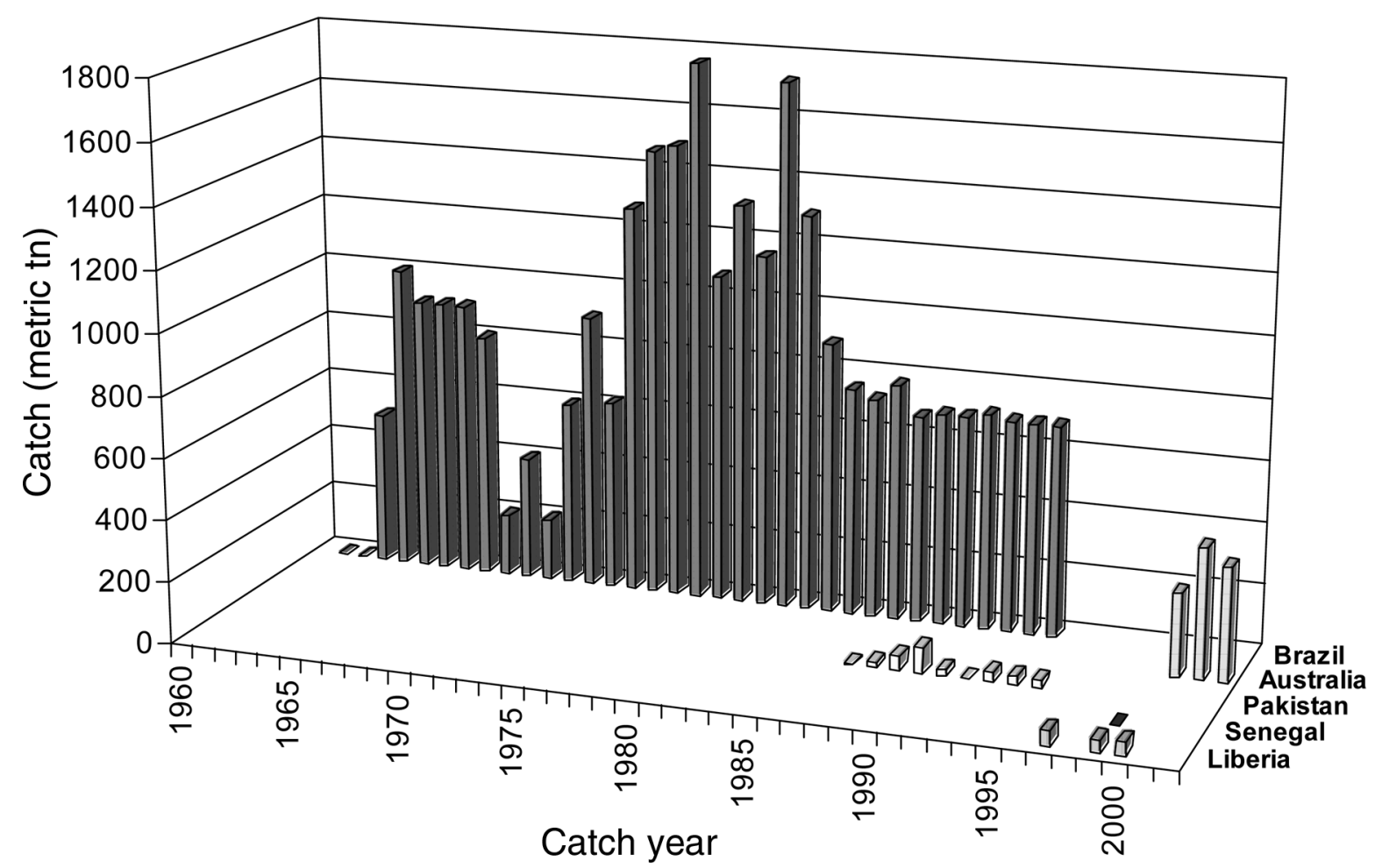

Figure 4. Yearly catches of pristids in metric tonnes by country, 1960-2002 (data from FAO Fishery Statistics, 2004).

areas with high flow rates, and Anoxypristis cuspidata seem to prefer river mouths with salinities of about 25-35 and very low flow rates (Thorburn et al., 2003). A $36-\mathrm{cm}$ female $P$. zijsron tracked acoustically for 27 hours in the Port Musgrave estuary of Western Australia moved $28.7 \mathrm{~km}$ at an average speed of about $28 \mathrm{~m} / \mathrm{min}$ and remained at all times within $200 \mathrm{~m}$ of the shore in very shallow water, averaging about $70 \mathrm{~cm}$ deep (Peverell \& Pillans, 2004). The preference for shallow water shown by P. zijsron in this study and the fact that it moved parallel to the shoreline suggests that pristids may occupy a relatively small area of available habitat that is concentrated in a narrow strip of water adjacent to the shoreline, at least during feeding. This is supported by studies on $P$. perotetti in North America where sawfish have been recorded along the shallow inshore regions of the coastline (Simpfendorfer, 2000). However, P. zijsron have also been recorded in water depths $>30 \mathrm{~m}$ along the east coast of Queensland (Peverell et al., 2004). Whether this record is typical of the species is unknown. In the Fitzroy River, Thorburn et al. (2004a,b) found a high abundance of $P$. microdon in the area immediately below the Camballin Weir and made six of eight recaptures there, concluding that pools below the Weir serve as refuge sites for this species during the dry season and that the Weir itself hinders its upstream migration.

In general, pristids feature restricted habitat ranges and are highly vulnerable to fisheries, resulting in serious population declines for most - if not all-species (Camhi et al., 1998). For example, in the late 19th Century, $P$. pectinata was extremely abundant in Florida, with one fisherman reporting accidental capture of 300 individuals in his nets in the Indian River during a single season (Bigelow \& Schroeder, 1953). By the late 20th Century, the species had been extirpated from the Indian River lagoon system (Snelson \& Williams, 1981). Adams et al. (2000) reviewed the status of $P$. pectinata, concluding that the population occurring in the United States (US) represents a distinct segment, identified five threats to this species' habitat, and determined that by-catch has played the main role in decline of the US population. In April 2003, the western Atlantic population of $P$. pectinata was listed as endangered and afforded federal protection under the United States Endangered Species Act, becoming the first elasmobranch to be included on the US Endangered Species List (United States Endangered Species Act, 2003). Pristid populations worldwide have been decimated by sport angling as well as incidental capture through extensive gill-netting and trawling in coastal, estuarine, and freshwater areas (Simpfendorfer, 2000). Their tooth rostra render all growth stages of pristids easily entangled in nets and almost impossible to remove without killing them (Camhi et al., 1998; Simpfendorfer, 2000).

Pristids yield valuable fisheries products and thus are landed when caught rather than released. The fins of all pristids are highly prized in the shark fin trade, the flesh of at least some species is edible, while the saw is used in traditional Chinese medicine and sold in the curio trade (Camhi et al., 1998). Pristids caught incidentally in northern Brazil are often processed for meat, fins and rostra (Charvet-Almeida, 2002). An estimated 1000-1500 pristid rostra (P. perotetti and $P$. pectinata) are sold annually at Vigia market, which is one of five major northern Brazilian markets trading in pristid rostra, and some 20 pristid rostra (mostly A. cuspidata, P. zijsron, and P. pectinata) are offered for sale on eBay each month, of which an average of 18 sell at a mean price of US\$119, generating 


\section{Carcharhinus}

1st dorsal fin height

$>2.5 \times$ height of $2 \mathrm{nd}$

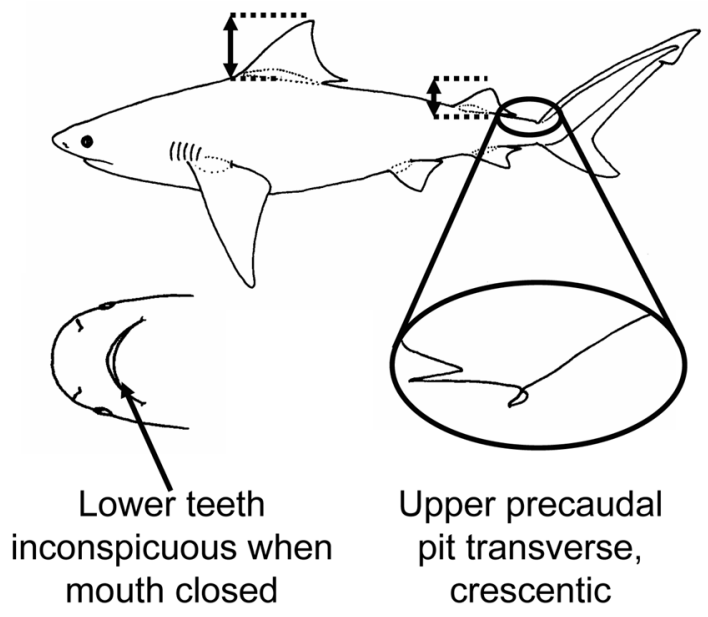

\section{Glyphis}

1st dorsal fin height

$1.7-2 \times$ height of 2 nd

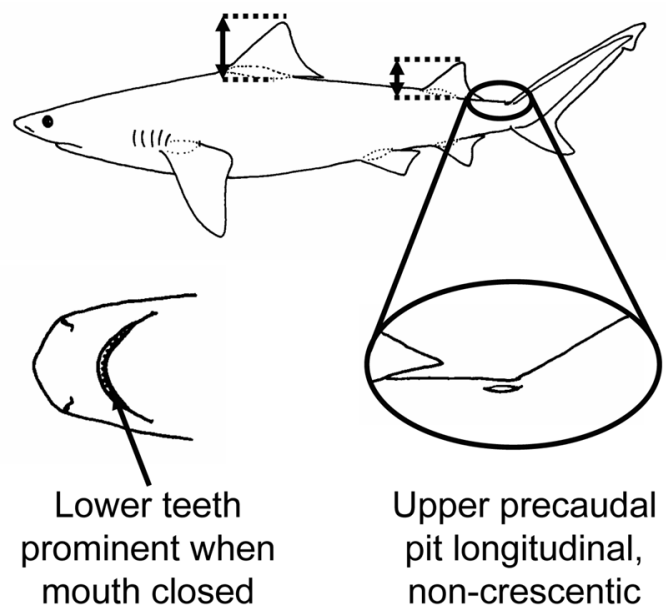

Figure 5. Illustrated key to differentiate Carcharhinus from Glyphis sharks.

an estimated US $\$ 25,000$ per annum (McDavitt \& Charvet-Almeida, 2004). The United States' motion in 1994 to list all pristid species on CITES Appendix I to stop trade in saws and fins was defeated because it could not be demonstrated that stopping trade in these products would protect wild populations of sawfish (Simpfendorfer, 2000; Cavanagh et al., 2003). Probably the best evidence of the impact of fishing on pristid population comes from Lake Nicaragua, where in the $1960 \mathrm{~s}$ the $P$. perotetti numbered in the hundreds of thousands, but had all but disappeared from the lake by the early 1980s (Thorson, 1982b). According to the Food and Agriculture Organization (FAO) of the United Nations fisheries statistics (FAO, 2004), Brazil has reported significant sawfish catches (up to 1750 tn per annum) from 1963-1994, Australia started reporting moderate captures (up to $450 \mathrm{tn}$ per annum) from 2000-2002, while Liberia, Pakistan, and Senegal have reported only minor landings (Figure 4). While FAO fisheries data are not without their limitations (no differentiation between target and by-catch landings of elasmobranchs; no standardization of fishing effort from year to year, etc.), the general trends they show may be reasonably accurate. The dramatic decline in pristid populations worldwide resulted in four species being listed on the IUCN Red List; $P$. perotetti is listed as critically endangered, while $P$. pectinata, $P$. pristis, and $P$. microdon are listed as endangered (Baillie \& Groombridge, 1996). More recent assessments by the IUCN Shark Specialist Group indicate that all pristid species are at least vulnerable, with most endangered or critically endangered (Simpfendorfer, 2000; Cavanagh et al., 2003).

Like other elasmobranchs, pristids are long lived and feature a low reproductive rate. Longevity of pristids is estimated to be about 30 years and what is known of their life history characteristics suggests low intrinsic rate of increase and rebound potential (Smith et al., 1998; Simpfendorfer, 2000). Using demographic models, Simpfendorfer (2000) estimated population doubling times of $P$. pectinata and $P$. perotetti is $5.4-8.5$ years and 10.3-13.5 years, respectively. He concluded that, if effective conservation measures could be implemented for sawfish and their habitats, recovery to levels where there is little risk of extinction would take at least several decades.

\section{Case history: Potamotrygonidae}

Potamotrygonids are endemic to South America and the only extant elasmobranch family restricted to freshwater habitats with salinities $<3$ (Brooks et al., 1981; Rosa, 1985; Compagno \& Cook, 1995a). They exhibit unique physiological features such as the inability to retain urea due to the absence of salt secretion via the rectal gland and modifications to the ampullae of Lorenzini (Thorson et al., 1978; Raschi \& Mackanos, 1996). Analysis of concentration of plasma components in some potamotrygonids has shown a typical teleostean blood chemistry that is very different from that of euryhaline dasyatids (Wood et al., 2002). As presently defined, the Potamotrygomidae comprises three genera, Paratrygon, Plesiotrygon, and Potamotrygon; I will here refrain from including an undescribed potamotrygonid (Ishihara \& Taniuchi, 1995) or other genera that have recently been hypothesized as being sister taxa to the river stingrays, notably amphi-American Himantura and Taeniura (Lovejoy, 1996; McEachran et al., 1996; McEachran \& Aschliman, 2004). Rosa et al. (1987) provide a key to potamotrygonid genera. Paratrygon is monotypical, represented by $P$. aiereba, is widely distributed in the Amazon and Orinoco river basins in northern Bolivia, eastern Peru, northern Brazil, and Venezuela, and bears only two 
young per litter (Compagno \& Cook, 1995a; Lasso et al., 1996). Plesiotrygon is also monotypical, represented by $P$. iwamae, occurs in upper- and mid-Amazon drainages of Equador and Brazil, and feeds on small catfish, insects, decapod crustaceans, and parasitic cestodes and nematodes (Rosa et al., 1987; Compagno \& Cook, 1995a). Potamotrygon contains 18 described species plus at least five undescribed species, with most species restricted to a single basin or river system (Compagno \& Cook, 1995a; Compagno, 1999a). For example, P. leopoldi is endemic to a single river, the Xingu River on the lower Amazon in Pará and Mato Grosso States, Brazil. In contrast, P. motoro and $P$. orbignyi are found in multiple river systems in tropical South America (Compagno \& Cook, 1995a). Distribution of river stingrays has recently been reviewed by Compagno \& Cook (1995a) and Araújo et al. (2004a). However, potamotrygonids feature a high degree of polychromatism and many species are inadequately described by morphological or genetic characters to allow accurate identification in the field (Araújo et al., 2004b; M.L.G. Araújo, Universidad Estadual do Amazonas, Manaus, personal communication).

Taxonomic problems within the Potamotrygonidae frustrate efforts to collect biological information, monitor fisheries, and conserve this group (Araújo, 1998). Until recently, virtually nothing was known of the diet, reproduction, life history, and ecology of potamotrygonids. Lasso et al. (1996), Araújo (1998), Charvet-Almeida (2001), and Bragança et al. (2004) provided data on the general biology of several species. As a group, potamotrygonids exploit diverse habitats in freshwater environments, including beach sands, flooded forest, small creeks with mud or stone bottoms, and lakes (Araújo et al., 2004a). In all habitats where they are found, potamotrygonids are apex predators, the adults of various species consuming mostly teleosts, annelids, and small crustaceans such as shrimps and isopods while the juveniles consume mostly small crustaceans and aquatic insects (Lasso et al., 1996; Charvet-Almeida, 2001). All species of potamotrygonid studied to date adhere to a matritrophic aplacental viviparous reproductive mode with uterine villi termed trophonemata, which nourish the embryo during gestation (Araújo et al., 2004a). The reproductive cycle of at least some potamotrygonids is strongly correlated to the hydrologic cycle; during the 1997-1998 El Niño, a prolonged drought in the Rio Negro enabled Potamotrygon cf. hystrix to undergo a second reproductive cycle rather than the usual single parturition (Araújo et al., 2004a; Charvet-Almeida et al., 2005). Gestation period of river stingrays varies enormously among species, ranging from three to 12 months; uterine fecundity ranges from one to eight pups per litter, with individual females giving birth in alternate years (Araújo et al., 2004a; Charvet-Almeida et al., 2005). Potamotrygonids have evolved at some interesting behavioural adaptations to their highly variable environment, including the ability to float on the surface when bottom water is hypoxic and exhibition of a form of maternal care, with neonates riding on the back of their mother for three or four days before assuming independent life (Achenbach \& Achenbach, 1976; Araújo, 1998).

The life histories of potamotrygonid stingrays are biologically constrained to a strongly K-selected pattern
Table 8. Economic and political issues affecting conservation of freshwater and euryhaline elasmobranchs.
Poverty
O Hunger
- Disease
$\bigcirc$ Inadequate education
Political Instability
- Civil strife
- Regional or civil wars
- Corruption
$\bigcirc$ Ineffective governance

Exploitation of New and Underutilized Stocks

- Targeted exploitation

- Food

- Leather

- Liver oil

- Pharmaceuticals

- Ornamental trade

- Curios

- Aquarium specimens

○y-catch

Tourism Development

○ Sport angling

O Anti-shark measures

inherent to elasmobranchs (Compagno \& Cook, 1995a; Camhi et al., 1998). Habitat constraints of potamotrygonids, such as restriction to freshwater habitats combined with habitat reduction during the dry season, render potamotrygonids more vulnerable to natural and anthropogenic impacts than marine elasmobranchs (Marques, 1996; Araújo et al., 2004b). Historically, potamotrygonids were not valuable to Amazon fishermen as food (Ferreira, 1886). However, these rays are now routinely captured in artesanal fisheries as a food or medicinal resource in certain regions of the lower Amazon drainage and, over the past 15 years, have become important in the ornamental fish trade (Araújo et al., 2004a,b). River stingrays comprise about $1 \%$ of the total ornamental fish exports from Manaus, Amazonas State, with at least six species (P. motoro, P. orbignyi, P. schroederi, P. leopoldi, P. henleyi, and Potamotrygon cf. hystrix) regularly exported and constituting $67 \%$ of all stingrays exported for this purpose (Araújo et al., 2004a,b). Throughout the Brazilian Amazon, the ornamental fish trade employs at least 10,000 families (Araújo et al., 2004b). Although several species of potamotrygonid occur in more than one country, Brazil is the only South American country that has regulations specifically to control the export of freshwater stingrays to supply the ornamental fish trade, with annual quotas for each of the six species that may be exported legally (Araújo et al., $2004 \mathrm{~b}, \mathrm{c}$ ). At least ten potamotrygonid species are exported from Brazil illegally (Araújo et al., 2004a). Since much potamotrygomid trade occurs in the border areas between Brazil and neighbouring nations, international cooperation is required to monitor this resource. For example, collection of $P$. aiereba for the ornamental fish trade is prohibited in Brazil, but this species is legally exported from Peru (Araújo et al., 2004c), creating opportunities for black market 'laundering' of specimens caught in Brazil. The negative public image of potamotrygonids 
and a desire to avoid accidents between visitors and these rays has encouraged some ecotourism companies to support removal of at least 21,000 individual rays (mainly $P$. aiereba and $P$. orbignyi) from the Rio Negro basin; this activity is not considered a 'fishery' by the Brazilian Environmental Agency and is thus unregulated (Araújo et al., 2004a). Educating local children and fishermen that potamotrygonids are beautiful, ecologically important, and vulnerable creatures and that at least some feed on insect larvae, thus helping to control infectious diseases such as yellow fever and malaria helps counter their negative perception; one recent public education event at Marabá city, Brazil, resulted in the collection of 1400 signatures on a petition to protect potamotrygonids (Charvet-Almeida, 2002; G. Rincón, UNESP-Universidade Estadual Paulista, Instituto de Biociências, Departamento de Ecologia, Brazil, personal communication). Commercial fisheries using trawl nets often catch river stingrays incidentally, introducing another unknown mortality rate on their stocks (Araújo et al., 2004b). Anthropogenic habitat degradation or destruction, such as through damming or dredging, may deplete freshwater stingrays more significantly than fisheries (Araújo et al., 2004b). Araújo et al. (2004b) conclude that the main problems in fishery management and conservation of potaomotrygonids in the Brazilian Amazon are incorrect species identifications and lost biological information.

\section{DISCUSSION}

Conservation problems and priorities

There are large gaps in our knowledge of the biology and status of freshwater and euryhaline elasmobranchs. The total diversity of elasmobranchs utilizing reduced salinity habitats is not known. Compagno \& Cook (1995a) estimated 44 species are found in fresh water far beyond the tidal influence of river mouths and an additional 25 species penetrate estuarine waters to some degree. But these authors did not include many Marginal and Brackish Marginal species from North America, South America, and Australia (Schwartz, 1995; Last, 2002; Ebert, 2003). The present study found at least 162 species occur in reduced salinity habitats, an increase of $135 \%$. However, in his survey of freshwater and estuarine elasmobranchs of Australia, Last (2002) listed 90 species known from various reduced salinity habitats and an additional 28 species deemed likely to be marginal in estuaries. If this pattern holds true on a global scale, as many as 220 species (about 20\%) of elasmobranchs may utilize reduced salinity habitats to some extent.

The conservation status of most freshwater and euryhaline elasmobranchs has not been determined. This is probably due to a combination of taxonomic problems and a general lack of the data absolutely vital to developing informed management or conservation strategies for these fish, such as distribution, population size and dynamics, habitat requirements, reproductive biology, life history, current levels of exploitation, and rates of anthropogenic habitat erosion or loss. Many freshwater and some euryhaline elasmobranchs are relatively rare and, due to their inherently low reproductive potential, can readily be driven to extinction as by-catch of fisheries supported by more abundant or more fecund species (Musick, 1995). At least some freshwater and euryhaline elasmobranch populations can be decimated within a few decades (Snelson \& Williams, 1981; Thorson, 1982a), underscoring the importance of not wasting time duplicating research that may already be completed for a given species under one or more synonyms.

Taxonomic problems also create difficulties for implementation of management and conservation plans. Laws cannot be enforced to protect what they cannot define and much valuable information about freshwater and euryhaline elasmobranchs is lost due to failure by both scientists and the general public to recognize threatened or endangered species. Glyphis sharks of tropical Australia are resilient compared with Carcharhinus leucas and C. amboinensis (Larson, 2000), and could feasibly be released alive if recognized in time. Valuable specimens of Glyphis have been lost due to misidentification in museum collections or even, in at least one case, being eaten by the fisherman who caught it (Compagno, 1984b, 1987, 2002; Last, 2002). Sharks of the genus Glyphis most closely resemble those of the genus Carcharhinus and are often confused with the Euryhaline C. leucas (Compagno, 1984a, 2002; Pogonoski et al., 2002). To assist differentiation of whole specimens of Glyphis from those of Carcharhinus in museum collections and in the field, a pictorial key is provided in Figure 5. Most species of sawfish are either endangered or critically endangered, but their taxonomy is highly unsettled. Some $60 \%$ of all potamotrygonids exported from Brazil for the ornamental fish trade consist of the undescribed species Potamotrygon cf. hystrix and incorrect species identifications of river stingrays frustrate attempts to monitor fisheries and accumulate biological data necessary for management of potamotrygnid stocks (Araújo et al., 2004b). Thus, resolution of taxonomic problems of freshwater and euryhaline elasmobranchs is an important first step toward developing effective research, monitoring, and conservation plans for these fish.

In a complex and dynamic biosphere that includes extinction as a normal component of evolution, one cannot reasonably expect to conserve everything. Myers (1997) introduced the medical concept of triage to conservation biology, prioritizing effort on those species and habitats that are at greatest risk but likely to survive if attended to urgently. Obligate Freshwater elasmobranchs with limited geographic ranges and populations of Euryhaline elasmobranchs that require access to the sea to breed may be most at risk of extinction due to anthropogenic habitat modification (Compagno \& Cook, 1995a). In contrast, the Euryhaline shark $C$. leucas is widely distributed and not restricted to reduced salinity habitats (Compagno, 1984a), and thus may be at less risk than Obligate Freshwater elasmobranchs or Euryhaline elasmobranchs with limited distributions. Therefore, of greatest concern are Glyphis sharks, pristids, potamotrygonid stingrays, and freshwater dasyatid stingrays of West Africa and south-east Asia. These taxa are simply those likely to be most at risk; whether or not they can be 'saved' and the ecological consequences of their extinction are not known.

The nature and extent of the ecological roles played by most species of freshwater and euryhaline elasmobranchs are not well understood. Given that these elasmobranchs are relatively unspecialized morphologically (Compagno, 1990b) and available dietary data suggests they are 
top-level predators wherever they occur (e.g. Bigelow \& Schroeder, 1953; Tuma, 1976; Compagno, 1984a, 1987; Lasso et al., 1996; Charvet-Almeida, 2001), it seems likely they occupy trophic levels comparable to those of their marine relatives and that depletion of their populations in reduced salinity ecosystems would exert top-down effects on population and diversity of their prey. Until the ecological role of freshwater and euryhaline elasmobranchs can be better elucidated, it seems prudent to adopt a precautionary approach and conserve their biodiversity and habitats as completely as practicable.

Humans are the greatest threat to freshwater and euryhaline elasmobranchs. Due to biological and habitat constraints, elasmobranchs that utilize reduced salinity environments are highly vulnerable to fishing pressure and anthropogenic habitat modification (Compagno \& Cook, 1995a,b,c). Virtually nothing is known about what constitutes critical habitat for freshwater and euryhaline elasmobranchs. In elasmobranchs, habitat selection is influenced by abiotic factors, such as temperature, salinity, depth, and bottom type, and biotic factors, such as benthic vegetation, prey distribution and availability, predator distribution, social organization, and reproductive activity (Simpendorfer \& Heupel, 2004). Access to pupping and nursery grounds is critical to the survival of the young of many elasmobranch species (Montoya \& Thorson, 1982; Branstetter, 1990; Castro, 1993; Morrissey \& Gruber, 1993a,b; Simpfendorfer \& Milward, 1993), yet the coastal, estuarine, riverine, and lacustrine areas where they occur are being destroyed and degraded at an alarming rate (Moyle \& Leidy, 1992; Camhi et al., 1998). In addition, a wide range of socio-economic factors influence the conservation of freshwater and euryhaline elasmobranchs (Table 8). Thus, any practical conservation strategy for freshwater and euryhaline elasmobranchs must take into account biological and habitat limitations, the effects of anthropogenic habitat modification, and socio-economic factors.

\section{Conservation strategies}

Conservation biology is a 'crisis discipline' established to deal with loss of species and the benefits of intact ecosystems (Soule, 1985). The IUCN has three basic conservation objectives: (1) secure the conservation of nature and particularly biodiversity for the future; (2) ensure the wise, equitable, and sustainable use of the earth's natural resources; and (3) guide the development of human communities toward ways of life that are both of good quality and in enduring harmony with other components of the biosphere (Fowler \& Camhi, 1998). The FAO has developed an International Plan of Action for Sharks (FAO, 1999), which urges member states that commercially harvest sharks (defined as any chondrichthyan fish) to undertake shark assessments and develop National Shark Management Plans that, inter alia, identify and pay special attention to vulnerable or threatened stocks. Thorburn et al. (2003) proposed conservation recommendations for freshwater and estuarine elasmobranchs of northern Australia, advocating a four-part strategy: (1) recognition and protection of aquatic ecosystems of special significance (such as where elasmobranch species of special concern, termed 'priority species', are relatively abundant); (2) closed or restricted access to aquatic areas where multiple priority species occur; (3) education of fishers in correct handling and release procedures for priority species; and (4) legislation protecting priority species. With these principles in mind and building on Compagno \& Cook (1995a), I propose the following annotated outline for a four-part action plan toward the conservation of freshwater and euryhaline elasmobranchs:

(1) Monitor populations

(a) Survey fisheries

(i) commercial fisheries (methods, catch per unit effort [CPUE] for targeted landings and bycatch, discard rate)

(ii) recreational fisheries (methods, landings)

(iii) control or 'negative' fisheries (methods, CPUE for targeted landings)

(iv) live collection for ornamental trade (methods, CPUE for targeted landings, mortality rate)

(v) products derived from fisheries (price paid to fishers, exporter, consumer)

(vi) waste produced by fisheries (quantity, rate, and type, organic and inorganic)

(vii) socio-economic factors (number employed, seasonality, annual earnings, educational and cultural background, etc.)

(b) Monitor catches
(i) species
(ii) sex
(iii) length
(iv) weight
(v) maturity stages
(vi) season/months fished
(vii) sites fished

(c) Estimate population sizes and trends of species taken in fisheries (fishery independent methods)

Monitoring catches will require training fishery workers in elasmobranch identification (Castro et al., 1999). Two ways to accomplish this are through offering training programmes and/or (if such do not already exist) development of inexpensive, user-friendly regional identification guides, such as the FAO Fisheries Identification Guides. Fishery independent methods of estimating population size include mark recapture (e.g. Seber, 1982).

(2) Encourage elasmobranch conservation in tropical countries

(a) foster a widespread conservation ethic

(b) share resources (expertise, manpower, funding)

Most elasmobranch conservation organizations are based in temperate countries, yet most freshwater and euryhaline elasmobranchs occur in tropical countries (Compagno \& Cook, 1995a). A cost-effective way to foster elasmobranch conservation among citizens and government officials is development of education programmes that increase awareness of the value of elasmobranchs as a living resource and their vulnerability to overfishing (Castro et al., 1999).

(3) Foster studies to fill in knowledge gaps

(a) address taxonomic problems 
(b) life history and ecology (Hoff \& Musick, 1990; Anderson, 1990)

(i) food habits

(ii) distribution

(iii) migratory route

(iv) nursery areas

(v) growth

(vi) age at size

(vii) size frequency

(viii) reproductive rate

(ix) age frequency

(x) stock structure

(xi) natural mortality

(xii) recruitment rate

(xiii) virtual population analysis

(xiv) predictive models

There is a relative paucity of experts in elasmobranch taxonomy. However, international organizations such as the FAO and IUCN maintain lists and contact details of global or regional experts who may be willing to assist in this regard. Pratt \& Otake (1990) suggest research in several categories of reproductive data that may be useful in managing fisheries. Cunningham-Day (2001) notes that scientists who fish for dissection specimens when sharks regularly become available through net mortality, by-catch, and illegal fishing hauls show poor use of resources.

(4) Develop management protocols

(a) identify threats

(b) identify priorities for conservation

(c) establish protected areas

(d) promote enforcement of existing legislation

(e) promote new legislation as needed

(f) manage fisheries to ensure long-term and sustainable use (Castro et al., 1999)

(i) effort should be commensurate with low reproductive capacity

(ii) minimize discards

(iii) maintain timely, complete, and reliable statistics on GPUE

Helfman et al. (1997) note that biodiversity loss is a symptom of anthropogenic environmental deterioration on a global scale and endangered species problems are really endangered habitat problems. I propose the following action plan for conserving freshwater and estuarine habitats, modified from McNeely et al. (1990):

(1) Develop and adopt methods that enable freshwater and estuarine habitats to be used for food, water, transportation, etc. in a sustainable manner.

(2) Select and adopt a series of protected areas covering the whole range of freshwater and estuarine ecosystems.

(3) Expand the concept of conservation policy and management to include maintenance of intraspecific variation of species of actual and potential socioeconomic importance and adopt measures that conserve as much as possible of other species whose qualities are not yet known.
(4) Consider national parks and other protected areas within the context of freshwater and estuarine use and the areas that surround them, design and operate them in ways acceptable to local people and that bring benefits to them in both the short- and long-term.

(5) Develop closer links between policies for conservation of ecosystems and genetic resources of priority species and promote measures that encourage recovery of natural vegetation to provide protection for soil and water catchment areas.

(6) Assemble basic biological information for the conservation of genetic diversity.

(7) Raise awareness, at all levels, of the importance of ecosystem and genetic resource conservation.

(8) Train staff to implement the objectives listed above.

National and international programmes to control human population growth are crucial to reversing local and global environmental deterioration (Becker, 1992). Beyond population control, other measures that may ameliorate habitat deterioration include establishment of biological preserves, restoration of impacted environments, and public education (Helfman et al., 1997). VaneWright (1997) proposed four principles that can be used to prioritize and focus conservation efforts: (1) efficiency, the minimum area representative of attributes of the whole habitat; (2) flexibility in area selection; (3) vulnerability, singling out habitats most likely to be targets of anthropogenic transformation; and (4) viability, setting realistic parameters likely to result in successful conservation of biodiversity.

It seems likely that successful conservation of freshwater and euryhaline elasmobranchs, even of endemic species with very restricted ranges, will require international cooperation. Reaka-Kudla et al. (1997) note that conservation of biodiversity requires cooperation among three components: institutional infrastructure, human resources, and inter-institutional links. Institutional infrastructure includes museums and their collections, state, national, and global biological surveys and data banks, and universities, institutes, governmental and nongovernmental organizations that support research, training, and conservation policy. Human resources consist of a small but expert community of systematists. Inter-institutional links serve to maximize shared human, financial, and institutional resources between museums, universities, government and non-governmental organizations. All these components are extant, although some are themselves endangered. Museums around the world are discontinuing research, laying off research staff, and putting their collections into off-site storage (J.D. McPhail, Curator Emeritus, University of British Columbia Fish Museum; J.A. Cosgrove, Chief of Natural History Collections, Royal British Columbia Museum; J.A. Seigel, Curator of Fishes, Los Angeles County Museum, personal communications). In addition, funding needs to be apportioned to support training and employment of systematists and biological collections managers (Reaka-Kudla et al., 1997). Despite the daunting logistical challenges involved, we must act quickly and efficiently if we are to have any hope of conserving freshwater and euryhaline elasmobranchs. If we do not, these creatures will exist only in the crumbling pages of historical accounts. 
This paper is greatly expanded from presentations given at the VI International Congress on the Biology of Fish, The Tropical Conference Center, 1-5 August, 2004, Manaus, Amazonas, Brazil, and at the 8th European Elasmobranch Association (EEA) Conference, Zoological Society of London, 21-24 October 2004, London, UK. I wish to thank Don MacKinlay, Fisheries and Oceans Canada, for inviting me to organize the VI International Congress on the Biology of Fish symposium 'Biology and conservation of freshwater elasmobranchs' and the Shark Trust for inviting me to participate in the 8th EEA meetings. Thanks also to my colleagues Maria L.G. Araújo, Universidad Estadual do Amazonas, Manaus; Getulio Rincón, UNESP-Universidade Estadual Paulista, Instituto de Biociências, Departamento de Ecologia, Brazil; H. Ishihara, Taiyo Engineering, Kyobashi, Chuoh-ku, Japan; T.R. Roberts, Research Associate, Smithsonian Tropical Research Institute, Panama; J.D. McPhail, Curator Emeritus, UBC Fish Museum; James A. Cosgrove, Chief of Natural History, Collections, RBCM; and Jeffrey A. Seigel, Curator of Fishes, LACM, for graciously sharing data and advice. Thanks to the $\mathcal{F} M B A$ Executive Editor A. Pulsford and two anonymous referees whose comments and suggestions were most helpful. Thanks to Eric B. Taylor, Curator UBC Fish Museum and the UBC Zoology Department for continued encouragement and support. Thanks also to Anne E. Martin, who prepared the tables and figures. This paper is respectfully dedicated to Abdul Azeez Abdul Hakeem, Director of the Banyan Tree Marine Laboratory, Vabbinfaru, Maldives; François Huet, Area General Manager, Banyan Tree Maldives; and Ho Kwon Ping, Chairman, Banyan Tree Resorts and Spas, in recognition of their on-going commitment to elasmobranch conservation.

\section{REFERENCES}

Achenbach, G.M. \& Achenbach, S.V.M., 1976. Notas acerca de algunas de raya fluvial (Batoidei, Potamotrygonidae), que frecuentam el sistema hidrografico del Rio Parana Medio en el Departmento La Capital. Comunicaciones del Museo Provincial de Ciencias Naturales Florentino Ameghino, 8, 3-34.

Adams, W.F., Bailey, C.M., Branstetter, S., Burgess, G.H., Lee, J.L. \& Musick, J.A., 2000. Status review of smalltooth sawfish (Pristis pectinata). National Marine Fisheries Service Status Report, $71 \mathrm{pp}$.

Adamson, R.H. \& Guarino, A.M., 1972. The effect of foreign compounds on elasmobranchs and the effect of elasmobranchs on foreign compounds. Comparative Biochemistry and Physiology, 42A, 171-182.

Anderson, E.D., 1990. Estimates of large shark catches in the western Atlantic and Gulf of Mexico, 1960-1986. In Elasmobranchs as living resources: advances in the biology, ecology, systematics, and the status of the fisheries (ed. H.L. Pratt Jr et al.) pp. 443-454. US Department of Commerce, NOAA Technical Report NMFS 90.

Araújo, M.L.G., 1998. Biologia reproductive e pesca de Potamotrygon sp. C (Condrichthyes-Potamotrygonidae), no Médio Rio Negro, Amazonas. MSc thesis, Instituto Nacional de Pesquitas da Amazônia and Universidade do Amazonas, Manaus, Brazil.

Araújo, M.L.G., Charvet-Almeida, P., Almeida, M.P. \& Pereira, H., 2004a. Freshwater stingrays (Potamotrygonidae): status, conservation and management challenges. Information Document AC20, 8, 1-6.

Araújo, M.L.G., Charvet-Almeida, P. \& Almeida, M.P., 2004b. Conservation status of freshwater stingrays (Chondrichthyes: Potamotrygonidae) in the Brazilian Amazon. In Biology and conservation of freshwater elasmobranchs: symposium proceedings, VI International Congress on the Biology of Fish, The Tropical Conference Center, 01-05 August 2004, Manaus, Amazonas, Brazil (ed. R.A. Martin and D. MacKinlay), pp. 61-71. Manaus, Brazil: Physiology Section, American Fisheries Society.
Araújo, M.L.G., Charvet-Almeida, P., Almeida, M.P. \& Pereira, H., 2004c. Conservation perspectives and management challenges for freshwater stingrays. Shark Newes, 16, 12-13.

Baillie, J. \& Groombridge, B., 1996. IUCN Red List of threatened animals. Cambridge: IUCN.

Baillie, J., Hilton-Taylor, C. \& Stuart, S.N., ed., 2004. 2004 IUCN Red List of threatened species: a global species assessment. Cambridge: IUCN-The World Conservation Union.

Bass, A.J., D'Aubrey, J.D. \& Kistnasamy, N., 1973. Sharks of the east coast of southern Africa. 1. The genus Carcharhinus (Carcharhinidae). Oceanographic Research Institute, Investigational Report, no. 39, 168 pp.

Baum, J.K. \& Myers R.A., 2004. Shifting baselines and the decline of pelagic sharks in the Gulf of Mexico. Ecology Letters, 7, 135-145.

Baum, J.K., Myers, R.A., Kehler, D.G., Worm, B., Harley, S.J. \& Doherty, P.A., 2003. Collapse and conservation of shark populations in the northwest Atlantic. Science, New York, 299, 389 392.

Becker, C.D., 1992. Population growth versus fisheries resources. Fisheries, 17 (5), 4-5.

Benke, A.C., Henry, R.L. III, Gillespie, D.M. \& Hunter, R.J., 1985. Importance of snag habitat for animal production in southeastern streams. Fisheries, 10(5), 8-13.

Berger, J.J., 1992. The Kissimmee riverine-floodplain system. In Restoration of aquatic ecosystems: science, technology and public policy (ed. National Research Council of the United States), pp. 477496. Washington DC: National Academy Press.

Betka, M. \& Callard, G.V., 1999. Stage-dependent accumulation of cadmium and induction of metallothionein-like binding activity in the testis of the dogfish shark, Squalus acanthias. Biology of Reproduction, 60, 14-22.

Bigelow, H.B. \& Schroeder, W.C., 1953. Fishes of the western north Atlantic. New Haven: Sears Foundation for Marine Research.

Bonfil, R., 1994. Overview of world elasmobranch fisheries. FAO Fisheries Technical Paper, 341, 1-119.

Bowen, W.D., 1997. Role of marine mammals in aquatic ecosystems. Marine Ecology Progress Series, 158, 267-274.

Bragança, A.J.M., Charvet-Almeida, P. \& Barthem, R.B., 2004. Preliminary observations on the feeding of the freshwater stingrays Potamotrygon orbignyi, Potamotrygon scobina, and Plesiotrygon iwamae (Chondrichthyes: Potamotrygonidae) in the Cotijuba Island Region-Para-Brazil. In Biology and conservation of freshwater elasmobranchs: symposium proceedings. VI International Congress on the Biology of Fish, The Tropical Conference Center, 01-05 August 2004, Manaus, Amazonas, Brazil (ed. R.A. Martin and D. MacKinlay), pp. 49-59. Manaus, Brazil: Physiology Section, American Fisheries Society.

Brander, K., 1981. Disappearance of the common skate Raja batis from the Irish Sea. Nature, London, 290, 48-49.

Branstetter, S., 1990. Early life-history implications of elected carcharhinoid and lamnoid sharks of the northwest Atlantic. NOAA Technical Report NMFS, 90, 17-28.

Branstetter, S. \& Stiles, R., 1987. Age and growth estimates of the bull shark, Carcharhinus leucas, from the northern Gulf of Mexico. Transaction of the American Fisheries Society, 123, 242254.

Breeder, C.M., Jr, 1952. On the utility of the saw of the sawfish. Copeia, 1952, 90-91.

Brooks, D.R., Thorson, T.B. \& Mayes, M.A., 1981. Freshwater stingrays (Potamotrgonidae) and their helminth parasites: testing hypotheses of evolution and coevolution. In Advances in cladistics. Proceedings of the First Meeting of the Willi Hennig Society, New York (ed. V.A. Funk and D.R. Brooks), pp. 147-175. Bronx, New York: The New York Botanical Garden.

Brooks, J. \& Dodson, S.I., 1965. Predation, body size, and composition of plankton. Science, New York, 150, 28-35.

Brunner, B., ed., 2004. Time Almanac 2005. Needham: Pearson Education. 
Budker, P., 1971. The life of sharks. London: Weidenfeld \& Nicolson.

Camhi, M., Fowler, S., Musick, J., Bräutigam, A. \& Fordham, S., 1998. Sharks and their relatives: ecology and conservation. Occasional Paper of the IUCN Species Survival Commission, no. 20, 39 pp.

Carpenter, S.R., Kitchell, J.F. \& Hodgson, J.R., 1985. Cascading trophic interactions and lake productivity. Bioscience, 35, 634-639.

Carr, J.R., 1993. Protecting ecological integrity: an urgent societal goal. Yale Fournal of International Law, 18, 297-306.

Casey, J. \& Myers, R., 1998. Near extinction of a large, widely distributed fish. Science, New York, 281, 690-692.

Castro, J.I., 1993. The shark nursery of Bulls Bay, South Carolina, with a review of the shark nurseries of the southeastern coast of the United States. Environmental Biology of Fishes, 38, 37-48.

Castro, J.I., Woodley, C.M. \& Brudek, R.L., 1999. A preliminary evaluation of the status of shark species. Rome: Food and Agriculture Organization of the United Nations.

Cavanagh, R.D., Kyne, P.M., Fowler, S.L., Musick, J.A. \& Bennett, M.B., ed., 2003. The conservation status of Australasian chondrichthyans. In Report of the IUCN Shark Specialist Group, Australia and Oceania Regional Red List Workshop, Queensland, Australia, 7-9 March 2003, pp.1-170. Brisbane: University of Queensland.

Charvet-Almeida, P., 2001. Ocorrência biologia e uso das raias de água doce na Baia de Marajó (Pará, Brasil), com ênfase na biologia de Plesiotrygon iwamae (Chondrichthyes: Potamotrygonidae). MSc thesis, Universidade Federal do Pará \& Museo Paraense Emilio Goeld, Para, Amazonas, Brazil.

Charvet-Almeida, P., 2002. Sawfish trade in the north of Brazil. Shark News, 14, 9.

Charvet-Almeida, P., Araújo, M.L.G. \& Almeida, M.P., 2005. Reproductive aspects of freshwater stingrays (Chondrichthyes: Potamotrygonidae) in the Brazilian Amazon Basin. Fournal of Northwest Atlantic Fishery Science, 35, 165-171.

Charvet-Almeida, P., Araújo, M.L.G., Rosa, R.S. \& Rincón, G., 2002. Neotropical freshwater stingrays: diversity and conservation status. Shark Newes, 14, 1.

Clark, E.H., Haversamp, J.A. \& Chapman, W., 1985. Eroding soils: the off-farm impacts. Washington DC: The Conservation Foundation.

Collins, S.L. \& Benning, T.L., 1996. Spatial and temporal patterns in functional diversity. In Biodiversity - a biology of numbers and difference (ed. K.J. Gaston), pp. 253-280. Oxford: Blackwell Science Limited.

Compagno, L.J.V., 1977. Phyletic relationships of living sharks and rays. American Zoologist, 17, 303-322.

Compagno, L.J.V., 1984a. FAO species catalogue. Vol. 4. Sharks of the world. An annotated and illustrated catalogue of shark species known to date. Part 2. Carcharhiniformes. Rome: Food and Agriculture Organization of the United Nations.

Compagno, L.J.V., 1984b. The mysterious Ganges shark. Ichthos, 7, 25-26.

Compagno, L.J.V., 1987. The French connection: return of the Ganges shark. Ichthos, 13, 8.

Compagno, L.J.V., 1988. Sharks of the order Carcharhiniformes. Princeton: Princeton University Press.

Compagno, L.J.V., 1990a. Shark exploitation and conservation. NOAA Technical Report NMFS, 90, 391-414.

Compagno, L.J.V., 1990b. Alternative life-history of cartilaginous fishes in time and space. Environmental Biology of Fishes, 28, 33-75.

Compagno, L.J.V., 1997. Threatened fishes of the world: Glyphis gangeticus (Müller \& Henle, 1839) (Carcharhinidae). Environmental Biology of Fishes, 49, 400.

Compagno, L.J.V., 1999a. Checklist of living elasmobranchs. In Sharks, skates, and rays: the biology of elasmobranch fishes (ed. W.C. Hamlett), pp. 471-498. Baltimore: Johns Hopkins University Press.
Compagno, L.J.V., 1999b. Systematics and body form. In Sharks, skates, and rays: the biology of elasmobranch fishes (ed. W.C. Hamlett), pp. 1-42. Baltimore: Johns Hopkins University Press.

Compagno, L.J.V., 2002. Freshwater and estuarine elasmobranch surveys in the Indo-Pacific region: threats, distribution and speciation. In Elasmobranch biodiversity, conservation and management: Proceedings of the International Seminar and Workshop, Sabah, Malasia, Fuly 1997 (ed. S.L. Fowler et al.), pp. 168-180. Gland \& Cambridge: IUCN SSC Shark Specialist Group.

Compagno, L.J.V. \& Cook, S.F., 1995a. The exploitation and conservation of freshwater elasmobranchs: status of the taxa and prospects for the future. Fournal of Aquariculture and Aquatic Sciences, 7, 62-90.

Compagno, L.J.V. \& Cook, S.F., 1995b. Through a glass darkly: a troubled future for freshwater elasmobranchs. Chondros, 6, 7-9.

Compagno, L.J.V. \& Cook, S.F., 1995c. Freshwater elasmobranchs: a questionable future. Shark Newes, 3, 4-6.

Compagno, L.J.V. \& Cook, S.F., 1995d. Status of the giant freshwater stingray (whipray) Himatura chaophraya (Monkolprasit \& Roberts, 1990). Shark Neres, 5, 5.

Compagno, L.J.V., Dando, M. \& Fowler, S., 2005. A field guide to sharks of the world. London: Collins.

Compagno, L.J.V., Ebert, D.A. \& Smale, M.J., 1989. Guide to the sharks and rays of southern Africa. London: New Holland (Publishers) Ltd.

Compagno, L.J.V. \& Neim, V.H., 1998. Carcharhinidae. In The living marine resources of the western central Pacific. Vol. 2. Cephalopods, crustaceans, holothurians and sharks (ed. K.E. Carpenter and V.H. Niem), pp. 1312-1360. Rome: FAO. [FAO Species Identification Guide for Fishery Purposes.]

Compagno, L.J.V. \& Roberts, T.R., 1982. Freshwater stingrays (Dasyatidae) of Southeast Asia and New Guinea, with description of a new species of Himantura and reports of unidentified species. Environmental Biology of Fishes, 7, 321-339.

Conroy, D.A., Morales, J., Perdomo, C., Ruiz, R.A. \& Santicana, J.A., 1981. Preliminary observations on ornamental fish diseases in northern South America. Revista Italiana di Piscicoltura e Ittiopatologia, 16, 86-98.

Cortés, E., 1999. Standardized diet compositions and trophic levels of sharks. ICES Fournal of Marine Science, 56, 707717.

Cortés, E., 2000. Life history patterns and correlations in sharks. Reviews in Fisheries Science, 8, 299-344.

Cunningham-Day, R., 2001 Sharks in danger: global shark conservation status with regard to management plans and legislation. Parkland: Universal Publishers.

Day, F., 1878. The fishes of India. London: B. Quaritch.

Derr, M., 1992. Raiders of the reef. Audubon, 94(2), 48-54.

Deynat, P.P., 2005. New data on the systematics and interrelationships of sawfishes (Elasmobranchii, Batoidea, Pristiformes). Fournal of Fish Biology, 66, 1477-1458.

Dulvy, N.K., Reynolds, J.D., Metcalfe, J.D. \& Glanvillem, J., 2000. Fisheries stability, local extinctions and shifts in community structure in skates. Conservation Biology, 14, 1-11.

Ebert, D.A., 2003. Sharks, rays and chimaeras of California. Berkeley: University of California Press.

Edmonds, G., 1989. Dangerous marine creatures. Frenchs Forest: Reed Books.

Ehrlich, P.R., Ehrlich, A.H. \& Holdren, J.P., 1973. Human ecology: problems and solutions. San Francisco: W.H. Freeman \& Company.

Elst van der, R., 1988. A guide to the common sea fishes of southern Africa, 2nd edn. Cape Town: Struik Publishers.

Elst van der, R.P., 1979. A proliferation of small sharks in the shore-based Natal sport fishery. Environmental Biology of Fishes, 4, 349-362. 
Estes, J. \& Palmisano, J., 1974. Sea otters, their role in structuring near-shore communities. Science, New York, 185 (4156), 1058-1060.

Evans, D.H., Piermarini, P.M. \& Choe, K.P., 2004. Homeostasis: osmoregulation, $\mathrm{pH}$ regulation, and nitrogen excretion. In Biology of sharks and their relatives (ed. J.C. Carrier et al.), pp. 247-268. Boca Raton: CRC Press.

Fairey, R., Taberski, K., Lamerdin, S., Johnson, E., Clark, R.P., Downing, J.W., Newman, J. \& Petreas, M., 1997. Organochlorines and other environmental contaminants in muscle tissues of sportfish collected from San Francisco Bay. Marine Pollution Bulletin, 34, 1058-1071.

FAO, 1999. International Plan of Action for reducing incidental catch of seabirds in longline fisheries. International Plan of Action for the conservation and management of sharks. International Plan of Action for the management of fishing capacity. Rome: FAO.

FAO, 2004. Fisheries Statistics. <http://www.fao.org/fi/statist/ fisoft/fishplus.asp >. Downloaded 26 November 2004.

Ferreira, A.R., 1886. Viagem Filosófica ao Rio Negro. Revista do Instituto Histórico Geográfico Brasileiro, XLIL(1), 123-188.

Fisk, A.T., Tittlemier, S.A., Pranschke, J.L. \& Norstrom, R.J., 2002. Using anthropogenic contaminants and stable isotopes to assess the feeding ecology of Greenland sharks. Ecology, 83, $2162-2172$

Forrester, C.R., Ketchen, K.S. \& Wong, C.C., 1972. Mercury content of spiny dogfish (Squalus acanthias) in the Strait of Georgia, British Columbia. Fournal of the Fisheries Research Board of Canada, 29, 1487-1490.

Fowler, S. \& Camhi, M., 1998. Shark Specialist Group update: action plan and report to CITES. In Shark management and conservation: Proceedings from the Sharks and Man workshop of the Second World Fisheries Congress, Brisbane, Australia, 2 August 1996 (ed. N.A. Gribble et al.), pp. 59-61. Brisbane: Queensland Department of Primary Industries.

Fowler, S.L., Reed, T.M. \& Dipper F.A., 2002. Elasmobranch biodiversity, conservation and management: Proceedings of the International Seminar and Workshop, Sabah, Malasia, July 1997. Gland \& Cambridge: IUCN SSG Shark Specialist Group.

Gaston, K.J., 1996. What is biodiversity? In Biodiversity - a biology of numbers and difference (ed. K.J. Gaston), pp. 1-9. Oxford: Blackwell Science Limited.

Glantz, M.H. \& Feingold, L.E., ed., 1990. Climate variability, climate change and fisheries. Coulder, Colorado: Environmental and Societal Impacts Group, National Center of Atmospheric Research.

Gleick, P.H., ed., 1993. Water in crisis: a guide to the world's fresh water resources. New York: Oxford University Press.

Goulding, M., 1980. The fishes and the forest. Explorations in Amazonian natural history. Berkeley: University of California Press.

Hamilton-Buchanan, F., 1822. An account of the fishes found in the River Ganges and its branches. Edinburgh: Archibald Constable \& Company.

Hardman, E.F., 1884. Sea-fish in fresh-water rivers. Nature, London, 29, 452-453.

Harmon, M.E. et al., 1986. Ecology of coarse woody debris in temperate ecosystems. Recent Advances in Ecological Research, 15, 133-302.

Helfman, G.S., Collette, B.B. \& Facey, D.E., 1997. The diversity of fishes. Malden: Blackwell Science, Inc.

Helm, T., 1976. Dangerous sea creatures: a complete guide to hazardous marine life. New York: Funk \& Wagnalls.

Hoenig, J.M. \& Gruber, S.H., 1990. Life-history patterns in the elasmobranchs: implications for fisheries management. NOAA Technical Report NMFS, 90, 1-16.

Hogarth, P.J., 1999. The biology of mangroves. Oxford: Oxford University Press.

Holden, M.J., 1974. Problems in the rational exploitation of elasmobranch populations and some suggested solutions. In Sea fisheries research (ed. H. Jones), pp. 117-137. New York: John Wiley \& Sons.
Hueter, R., ed., 1998. Science and management of shark fisheries: proceedings of an international symposium held at the 125th Annual Meeting of the American Fisheries Society, Tampa, Florida, USA, 30 August, 1995. Fisheries Research, 39(2), 105-228.

International Institute for Environment and Development and World Resources Institute, 1987. World resources 1987. New York: Basic Books.

Ishihara, H. \& Taniuchi, T., 1995. A strange potamotrygonid ray (Chondrichthyes: Potamotrygonidae) from the Orinoco River system. Fournal of Aquariculture and Aquatic Sciences, 7, 91-97.

Ishihara, H., Wu, H., Li, S. \& Homma, K., 2005. Dasyatis sp. distributed in the upper stream of Zhu River, Guanggion District, China. 7th Indo-Pacific Fish Conference, Howard International Hotel, Taipei, Taiwan, 16-20 May 2005. [Abstract Book.]

Jensen, N.H., 1976. Reproduction of the bull shark, Carcharhinus leucas, in the Lake Nicaragua-Rio San Juan system. In Investigation of the ichthyofauna of Nicaraguan lakes (ed. T.B. Thorson), pp. 539-559. Lincoln: University of Nebraska.

Krebs, C.J., 1994. Ecology: the experimental analysis of distribution and abundance, 4th edn. New York: Harper Collins College Publishers.

Lal Mohan, R.S., 1986. Can a sawfish (Pristis sp.) kill a dugong? Sirenews, 6, 7.

Larson, H., 2000. Threatened fish profile: northern speartooth shark Glyphis sp. C. Newesletter of the Australian Society for Fish Biology, 30, 1.

Larsson, U., Rosenberg, R. \& Edler, L., 1986. Eutrophication in marine waters surrounding Sweden: a review. National Swedish Environmental Protection Board.

Lasso, C.A., Rial, A.B. \& Lasso-Alcalá, O., 1996. Notes on the biology of the freshwater stingrays Paratrygon aiereba (Müller \& Henle, 1841) and Potamotrygon orbignyi (Castelnau, 1855) (Chondrichthyes: Potamotrygonidae) in the Venezuelan llanos. Aqua fournal of Ichthyology and Aquatic Biology, 2(3), 3952.

Last, P.R., 2002. Freshwater and estuarine elasmobranchs of Australia. In Elasmobranch biodiversity, conservation and management: Proceedings of the International Seminar and Workshop, Sabah, Malasia, Fuly 1997 (ed. S.L. Fowler et al.), pp. 185-193. Gland \& Cambridge: IUCN SSC Shark Specialist Group.

Last, P.R. \& Stevens, J.D., 1994. Sharks and rays of Australia. CSIRO Australia.

Lévêque, G. \& Mounolou, J.-C., 2003. Biodiversity. Chichester: John Wiley \& Sons Ltd.

Li, H.W., Schreck, C.B., Bond, C.E. \& Rexstad, E., 1987. Factors affecting fish assemblages of Pacific Northwest streams. In Community and evolutionary ecology of North American stream fishes (ed. W.J. Matthews and D.C. Heins), pp. 193-202. Norman: University of Oklahoma Press.

Little, C., 2000. The biology of soft shores and estuaries. Oxford: Oxford University Press.

Lovejoy, N.R., 1996. Systematics of myliobatoid elasmobranchs: with emphasis on the phylogeny and historical biogeography of neotropical freshwater stingrays (Potamotrygonidae: Rajiformes). Zoological Fournal of the Linnean Society, 117, 207-257.

Lowe-McConnell, R.H., 1987. Ecological studies in tropical fish communities. Cambridge: Cambridge University Press.

MacFadyen, A., 1957. Animal ecology — aims and methods, lst edn. London: Sir Isaac Pitman \& Sons.

Manire, C.A. \& Gruber, S.H., 1990. Many sharks may be headed toward extinction. Conservation Biology, 4, 10-11.

Manjaji, B.M., 2002. Elasmobranchs recorded from rivers and estuaries in Sabah. In Elasmobranch biodiversity, conservation and management: Proceedings of the International Seminar and Workshop, Sabah, Malasia, July 1997 (ed. S.L. Fowler et al.), pp. 168-180. Gland \& Cambridge: IUCN SSC Shark Specialist Group. 
Marques, J.F.B., 1996. Regulação de amônia e uréia de Potamotrygon sp. (Chondrichtyes: Potamotrygonidae) em aguas Amazônicas. MSc thesis, Instituto Nacional de Pesquisas da Amazônia and Universidadedo Amazonas, Manaus, Brazil.

Master, L., 1990. The imperilled status of North American aquatic animals. Biodiversity Network News, 3(3), 1-2, 7-8.

McCormick, H.W., Allen, T. \& Young, W., 1963. Shadowe in the sea: the sharks, skates and rays. Philadelphia: Chilton Book Company.

McDavitt, M.T. \& Charvet-Almeida, P., 2004. Quantifying trade in sawfish rostra: two examples. Shark Newes, 16, 10-11.

McEachran, J.D. \& Aschliman, N., 2004. Phylogeny of Batoidea. In Biology of sharks and their relatives (ed. J.C. Carrier et al.), pp. 79-135. Boca Raton: CRC Press.

McEachran, J.D., Dunn, K.A. \& Miyake, T., 1996. Interrelationships of the batoid fishes (Chondrichthyes: Batoidei). In Interrelationships of fishes (ed. M.L.J. Stiassny et al.), pp. 63-84. San Diego: Academic Press.

McNeely, J.A., Miller, K.R., Reid, W.V., Mittermeier, R.A. \& Werner, T.B., 1990. Conserving the world's biological diversity. Gland: IUCN Publications Services

Mearns, A.J., Matta, M.B., Simacel-Beatty, D., Buchman, M.F., Shienaka, G. \& Wert, W.A., 1988. PCB and chlorinated pesticide contamination in U.S. fish and shellfish: a historical assessment report. Rockville, Maryland: NOAA, Department of Commerce. [NOAA Technical Memorandum, NOS OMA 39.]

Michael, S.W., 1993. Reef sharks and rays of the world: a guide to their identification, behavior, and ecology. Monterey: Sea Challengers.

Miller, J.M., Pietrafesca, L.J. \& Smith, N.P., 1990. Principles of hydraulic management of coastal lagoons for aquaculture and fisheries. FAO Fisheries Biology Technical Paper, no. 314, $1-88$.

Miller, W.A., 1995. Rostral and dental development in sawfish (Pristis perotteti). Fournal of Aquariculture and Aquatic Sciences, 7, 98-107.

Mills, K.H. \& Schindler, D.W., 1986. Biological indicators of lake acidification. Water, Air and Soil Pollution, 30, 779-789.

Monkolprasit, S. \& Roberts, T.R., 1990. Himantura chaophraya, a new giant freshwater stingray from Thailand. Fapanese fournal of Ichthyology, 37, 203-208.

Montoya, R.V. \& Thorson, T.B., 1982. The bull shark (Carcharhinus leucas) and largetooth sawfish (Pristis perotteti) in Lake Bayano, a tropical man-made impoundment in Panama. Environmental Biology of Fishes, 7, 341-347.

Morrissey, J.F. \& Gruber, S.H., 1993a. Habitat selection by juvenile lemon sharks, Negaprion brevirostris. Environmental Biology of Fishes, 38, 311-319.

Morrissey, J.F. \& Gruber, S.H., 1993b. Home range of juvenile lemon sharks, Negaprion brevirostris. Copeia, 1993, 425-434.

Moyle, P.B., 1976. Inland fishes of California. Berkeley: University of California Press.

Moyle, P.B. \& Leidy, R.A., 1992. Loss of biodiversity in aquatic ecosystems; evidence form fish faunas. In Conservation biology (ed. P.L. Fiedler and S.K. Jain), pp.127-169. Routledge: Chapman \& Hall.

Müller, J. \& Henle, J., 1838-1841. Systematische beschreibung der Palgiostomen. Berlin: Von Veit \& Company.

Murdy, E.O., Birdsong, R.S. \& Musick, J.A., 1997. Fishes of Chesapeake Bay. Washington DC: Smithsonian Institution Press.

Murray, J.D., Bahen, J.J. \& Rulifson, R.A., 1992. Management considerations for by-catch in the North Carolina and Southeast shrimp fishery. Fisheries, 17, 21-26.

Musick, J.A., 1995. Critically endangered large coastal sharks, a case study: the sandbar shark, Carcharhinus plumbeus (Nardo, 1827). Shark Newes, 5, 6-7.

Musick, J.A., Burgess, G., Cailliet, G., Camhi, M. \& Fordham, S., 2000. Management of sharks and their relatives (Elasmobranchii). Fisheries, 25(3), 9-13.
Myers, G.S., 1952. Sharks and sawfishes of the Amazon. Copeia, 1952, 268-269.

Myers, N., 1997. The rich diversity of biodiversity issues. In Biodiversity II: understanding and protecting our biological resources (ed. M.L. Reaka-Kudla et al.), pp. 125-138. Washington DG: Joseph Henry Press.

Nichols, S., Shah, A., Pellegrin, G.J. Jr \& Mullin, K., 1990. Updated estimates of shrimp fleet by-catch in the offshore waters of the Gulf of Mexico 1972-1989. Pascagoula, Mississippi: National Marine Fisheries Service.

Odum, E.P., 1975. Diversity as a function of energy flow. In Unifying concepts in ecology (ed. W.H. van Dobben and R.H. Lowe-McConnell), pp. 11-14. The Hague, Netherlands: Dr W. Junk BV Publishers.

Oviedo y Valdés, G.F., 1526. De la natural hystoria de las Indias. Toledo, Spain. English translation: Natural History of the West Indies, University of North Carolina studies in the romance languages No. 32 (ed. S.A. Stoudemire). Chapel Hill: University of North Carolina Press, 1959.

Paine, R.T., 1966. Food web complexity and species diversity. American Naturalist, 100, 65-75.

Palmer, T., 1984. Lifelines: the case for river conservation. Washington DC: Island Press.

Payne, A.I., 1986. The ecology of tropical lakes and rivers. New York: John Wiley \& Sons.

Perra, P., 1992. By-catch reduction devices as a conservation measure. Fisheries, 17, 28-29.

Peverell, S.C., Gribble, N.A. \& Larson, H., 2004. Sawfish. In Description of key species groups in the Northern Planning Area (ed. P. Whitehead), pp. 75-83. Hobart, Australia: National Oceans Office.

Peverell, S. \& Pillans, R., 2004. Determining feasibility of acoustic tag attachment and documenting short-term movements in Pristis zijsron Bleeker, 1851. Report for the National Oceans Office, Hobart, 1-18.

Pierce, R.H. \& Rand, G.M.R., 1997. Evaluation of biological indicators for assessment and prediction of adverse ecological impacts from contaminants in coastal ecosystems. Final Report, US EPA Gulf of Mexico Program. Mote Marine Laboratory Technical Report, 538, 71 pp. + tables and appendices.

Pogonoski, J.J., Pollard, D.A. \& Paxton, J.R., 2002. Conservation overview and action plan for Australian threatened and potentially threatened marine and estuarine fishes. Canberra: Environment Australia.

Pratt, H.L. Jr \& Casey, J.G., 1990. Shark reproductive strategies as a limiting factor in directed fisheries, with a review of Holden's method of estimating growth parameters. NOAA Technical Report NMFS, 90, 97-109.

Pratt, H.L. Jr \& Otake, T., 1990. Recommendations for work needed to increase our knowledge of reproduction relative to fishery management. NOAA Technical Report NMFS, 90, 509510.

Primack, R.B., 1998. Essentials of conservation biology, 2nd edn. Sunderland, MA: Sinauer Associates Publishers.

Raschi, W. \& Mackanos, L.A., 1989. The structure of ampullae of Lorenzini in Dasyatis garouaensis and its implication on the evolution of the freshwater eletroreceptive system. Fournal of Experimental Zoology, Supplement 2, 101-111.

Reaka-Kudla, M.L., Wilson, D.E. \& Wilson, E.O., 1997. Santa Rosalia, the turning of the century, and a new age of exploration. In Biodiversity II: understanding and protecting our biological resources (ed. M.L. Reaka-Kudla et al.), pp. 507-524. Washington DC: Joseph Henry Press.

Redding, J.M., 1992. Effects of heavy metals on DNA synthesis in the testis of dogfish (Squalus acanthias). Bulletin of the Mount Desert Island Biological Laboratory, 31, 42-43.

Renfrew, C. \& Bahn, P., 1996. Archaeology: theories, methods and practice, 2nd edn. New York: R.R. Donnelley \& Sons Company. 
Ricklefs, R.E., 1990. Ecology, 3rd edn. New York: W.H. Freeman \& Company.

Roberts, T.R., 2005. Debunking the mythology of the so-called 'freshwater shark of the Ganges', Glyphis gangeticus (Elasmobranchii, Carcharhinidae). In 7th Indo-Pacific Fish Conference, Howard International Hotel, Taipei, Taiwan, 16-20 May 2005 (ed. S. Kwang-Tsao), p. 30. Academica Sinica, Taipei: Ichythological Society of Taiwan. [Abstract Book.]

Roberts, T.R. \& Karnasuta, J., 1987. Dasyatis laosensis, a new whiptailed stingray (family Dasyatidae), from the Mekong River of Laos and Thailand. Environmental Biology of Fishes, 20 (3), 161-167.

Rosa, R.S., 1985. A systematic revision of the South American freshwater stingrays (Chondrichthyes: Potamotrygonidae). $\mathrm{PhD}$ thesis, College of William and Mary, Williamsburg, Virginia, USA.

Rosa, R.S., Castello, H.P. \& Thorson, T.B., 1987. Plesiotrygon iwamae, a new genus and species of neotropical freshwater stingray (Chondrichthyes: Potamotrygonidae). Copeia, 1987, 447458.

Schäfer, F., 2001. Mind your step! In Sharks and rays: elasmobranch guide to the world (ed. R.M. Hennemann), pp. 221-223. Frankfurt, Germany: IKAN - Unterwasserarchiv.

Schofield, C.L., 1988. Lake acidification in wilderness areas: an evaluation of impacts and options for rehabilitation. In Ecosystem management for parks and wilderness (ed. J.K. Agee and D.R. Johnson), pp. 135-144. Seattle: University of Washington Press.

Schwartz, F.J., 1995. Elasmobranchs frequenting fresh and low saline waters of North Carolina during 1971-1991. Fournal of Aquariculture and Aquatic Sciences, 7, 45-51.

Seber, G.A.F., 1982. The estimation of animal abundance and related parameters. London: Charles Griffin \& Company.

Senanyake, F.R. \& Moyle, P.B., 1982. Conservation of the freshwater fishes of Sri Lanka. Biological Conservation, 2, 149-156.

Serrano, R., Fernandez, M.A., Hernandez, L.M., Hernandez, M., Pascual, P., Rabanal, R.M. \& Gonzalez, M.J., 1997. Coplanar polychlorinated biphenyl congeners in shark livers from the north-western African Atlantic Ocean. Bulletin of Environmental Contamination and Toxicology, 58, 150-157.

Sezaki, K. et al., 1999. Molecular phylogeny of Asian freshwater and marine stingrays based on DNA nucleotide and deduced amino acid sequences of the cytochrome $b$ Gene. Fisheries Biology, 65, 563-570.

Simpfendorfer, C.A., 2000. Predicting population recovery rates for endangered western Atlantic sawfishes using demographic analysis. Environmental Biology of Fishes, 58, 371-377.

Simpfendorfer, C.A. \& Heupel, M.R., 2004. Assessing habitat use and movement. In Biology of sharks and their relatives (ed. J.C. Carrier et al.), pp. 247-268. Boca Raton: CRC Press.

Simpfendorfer, C.A. \& Milward, N.E., 1993. Utilisation of a tropical bay as a nursery area by sharks of the families Carcharhinidae and Sphyrnidae. Environmental Biology of Fishes, 37, 337-345.

Simpson, P.W., Newman, J.R., Kevin, M.A., Matter, R.M. \& Guthrie, R.A., 1982. Manual of stream channelization impacts on fish and wildlife. US Fish and Wildlife Service, Office of Biological Services, Report no. 82/24. Washington DC: US Fish and Wildlife Service.

Skelton, P.H., 1987. South African red data book-fishes. South African National Scientific Programmes, Report no. 137.

Smith, P.J., Francis, R.I.C.C. \& McVeagh, M., 1991. Loss of genetic diversity due to fishing pressure. Fisheries Research, 10, 309-316.

Smith, S.E., Au, D.W. \& Show, C., 1998. Intrinsic rebound potentials of 26 species of Pacific sharks. Marine and Freshwater Research, 49, 663-678.

Snelson, F.F. \& Williams, S.E., 1981. Notes on the occurrence, distribution, and biology of elasmobranch fishes in the Indian River lagoon system, Florida. Estuaries, 4(2), 110-120.
Soule, M.E., 1985. What is conservation biology? Bioscience, 35, 727-734.

Stevens, J.D., Bonfil, R., Dulvy, N.K. \& Walker, P.A., 2000. The effects of fishing on sharks, rays, and chimaeras (chondrichthyans), and the implications for marine ecosystems. ICES Journal of Marine Science, 57, 476-494.

Strong, W.R., Jr, 1991. Instruments of natural selection: how important are sharks? In Discovering sharks: a volume honouring the work of Stewart Springer (ed. S.H. Gruber), pp. 70-73. Highlands, New Jersey: American Littoral Society.

Tanaka, S., 1991. Age estimation of the freshwater sawfish and sharks in northern Australia and Papua New Guinea. University Museum, University of Tokyo, Nature and Culture, 3, 7182.

Tanaka, S. \& Ohnishi, S., 1998. Some biological aspects of freshwater stingrays collected from Chao Phraya, Mekong, and Ganges River systems. In Adaptability and conservation of freshwater elasmobranchs. Report of Research Project, Grant-in-Aid for International Scientific Research (Field Research) in the financial year of 1996 and 1997 (ed. S. Tanaka), pp. 102-109. Shimizu, Japan: School of Marine Science and Technology, Tokai University.

Taniuchi, T., 2002. Outline of field surveys for freshwater elasmobranchs conducted by a Japanese research team. In Elasmobranch biodiversity, conservation and management: Proceedings of the International Seminar and Workshop, Sabah, Malasia, July 1997 (ed. S.L. Fowler et al.), pp. 181-184. Gland \& Cambridge: IUCN SSC Shark Specialist Group.

Taylor, J.N., Courtenay, W.R. Jr \& McCann, J.A., 1984. Known impacts of exotic fishes in the continental United States. In Distribution, biology, and management of exotic fishes (ed. W.R. Courtenay Jr and J.R. Stauffer Jr), pp. 322-373. Baltimore: Johns Hopkins University Press.

Thomerson, J.E., Thorson, T.B. \& Hempel, R.L., 1977. The bull shark, Carcharhinus leucas, from the upper Mississippi River, near Alton, Illinois. Copeia, 1977, 166-168.

Thorburn, D. \& Morgan, D., 2004. The northern river shark Glyphis sp. G (Carcharhinidae) discovered in Western Australia. Zootaxa, 685, 1-8.

Thorburn, D. et al., 2004a. Biology and cultural significance of the freshwater sawfish (Pristis microdon) in the Fitzroy River, Kimberley, Western Australia. Report to Threatened Species Network, Sydney.

Thorburn, D., Morgan, D., Rowland, A.J. \& Gill, H., 2004 b. Elasmobranchs in the Fitzroy River, Western Australia. Report to Natural Heritage Trust, Canberra.

Thorburn, D.C., Peverell, S.C., Stevens, J.D., Last, P.R. \& Rowland, A.J., 2003. Status of freshwater and estuarine elasmobranchs in Northern Australia. Report to Natural Heritage Trust, Canberra.

Thorson, T.B., 1971. Movement of bull sharks, Carcharhinus leucas, between Caribbean Sea and Lake Nicaragua demonstrated by tagging. Copeia, 1971, 336-338.

Thorson, T.B., 1976a. Observations on the reproduction of the sawfish, Pristis perotteti, in Lake Nicaragua, with recommendations for its conservation. In Investigations of the ichthyofauna of Nicaraguan lakes (ed. T.B. Thorson), pp. 641-650. Lincoln: University of Nebraska.

Thorson, T.B., 1976b. The status of the Lake Nicaragua shark: an updated appraisal. In Investigations of the ichthyofauna of Nicaraguan lakes (ed. T.B. Thorson), pp. 561-574. Lincoln: University of Nebraska.

Thorson, T.B., 1982a. Age, growth rate and longevity of Carcharhinus leucas estimated from tagging and vertebral rings, Copeia, 1982, 110-116.

Thorson, T.B., 1982b. Life history implications of a tagging study of the largetooth sawfish, Pristis perotteti, in the Lake Nicaragua-Rio San Juan system. Environmental Biology of Fishes, 7, 207-228. 
Thorson, T.B., 1982c. The impact of commercial exploitation of sawfish and shark populations in Lake Nicaragua. Fisheries $7(2), 2-10$.

Thorson, T.B., 1983. Observations on the morphology, ecology and life history of the euryhaline stingray, Dasyatis guttata (Block \& Schneider) 1801. Acta Biologica Venezuelica, 11 (4), 95-125.

Thorson, T.B., Langhammer, J.K. \& Oetinger, M.I., 1983. Reproduction and development of the South American freshwater stingrays, Potamotrygon circularis and $P$. motoro. Environmental Biology of Fishes, 9, 3-24.

Thorson, T.B., Wooton, R.M. \& Georgi, T.A., 1978. Rectal gland of freshwater stingrays Potamotrygon spp. (Chondrichthyes: Potamotrygonidae). Biological Bulletin. Marine Biological Laboratory, Woods Hole, 154, 508-516.

Tuma, R.E., 1976. An investigation of the feeding habits of the bull shark, Carcharhinus leucas, in the Lake Nicaragua-Rio San Juan system. In Investigation of the ichthyofauna of Nicaraguan lakes (ed. T.B. Thorson), pp. 533-538. Lincoln: University of Nebraska.

US Congress Office of Technology Assessment, 1987. Waters in marine environments. Washington DC: US Government Printing Office.

US Endangered Species Act, 2003. Status of the smalltooth sawfish in US waters. Federal Register, 66 (73), 19414-19420.

Vane-Wright, R.I., 1996. Identifying priorities for the conservation of biodiversity: systematic biological criteria within a socio-political framework. In Biodiversity - a biology of numbers and difference (ed. K.J. Gaston), pp. 309-344. Oxford: Blackwell Science Limited.

Verrill, A.H., 1948. Strange fish and their stories. Boston: Page \& Company.

Vidthayanon, C., 2002. Elasmobranch diversity and status in Thailand. In Elasmobranch biodiversity, conservation and management: Proceedings of the International Seminar and Workshop, Sabah, Malasia, Fuly 1997 (ed. S.L. Fowler et al.), pp. 104-113. Gland \& Cambridge: IUCN SSC Shark Specialist Group.
Walker, T.I., 1988. Mercury concentrations in edible tissues of elasmobranchs, teleosts, crustaceans and molluscs from southeastern Australian waters. Australian Fournal of Marine and Freshwater Research, 39, 39-49.

Wallace, J.B. \& Benke, A.C., 1984. Quantification of wood habitat in substropical coastal plain streams. Canadian fournal of Fisheries and Aquatic Sciences, 41, 1643-1652.

Welcomme, R.L., 1985. River fisheries. FAO Technical Paper, no. 262. Rome: FAO.

Whigham, D.F., Chitterling, C. \& Palmer, B., 1988. Impacts of freshwater wetlands on water quality: a landscape perspective. Environmental Management, 12, 663-674.

Williams, J.D., Warren, M.L., Cummings, K.S., Harris, J.L. \& Neves, R.J., 1993. Conservation status of freshwater mussels of the United States and Canada. Fisheries, 18, 6-22.

Wilson, E.O., 1980. Sociobiology — the abridged edition. Cambridge: Harvard University Press.

Witte, F., Goldschmidt, T., Goudswaard, P.G., Ligtvoet, W., Oijen, M.J.P. von \& Wanink, J.H., 1992. Species extinction and concommitant ecological changes in Lake Victoria. Netherlands Fournal of Zoology, 42, 214-232.

Wood, C.M., Matsuo, A.Y.O., Gonzalez, R.J., Wilson, R., Patrick, M.L. \& Val, A.L., 2002. Mechanism of ion transport in Potamotrygon, a stenohaline freshwater elasmobranch native of the ion blackwater of the Rio Negro. Journal of Experimental Biology, 205, 3039-3054.

Zorzi, G.D., 1995. The biology of freshwater elasmobranchs: an historical perspective. Fournal of Aquariculture and Aquatic Sciences, 7, 10-31.

Submitted 2 February 2005. Accepted 13 Fuly 2005. 